Water Availability and Use Science Program

Prepared in cooperation with the city of Santa Cruz

\title{
Storage Capacity and Sedimentation Characteristics of Loch Lomond Reservoir, California, 2019
}

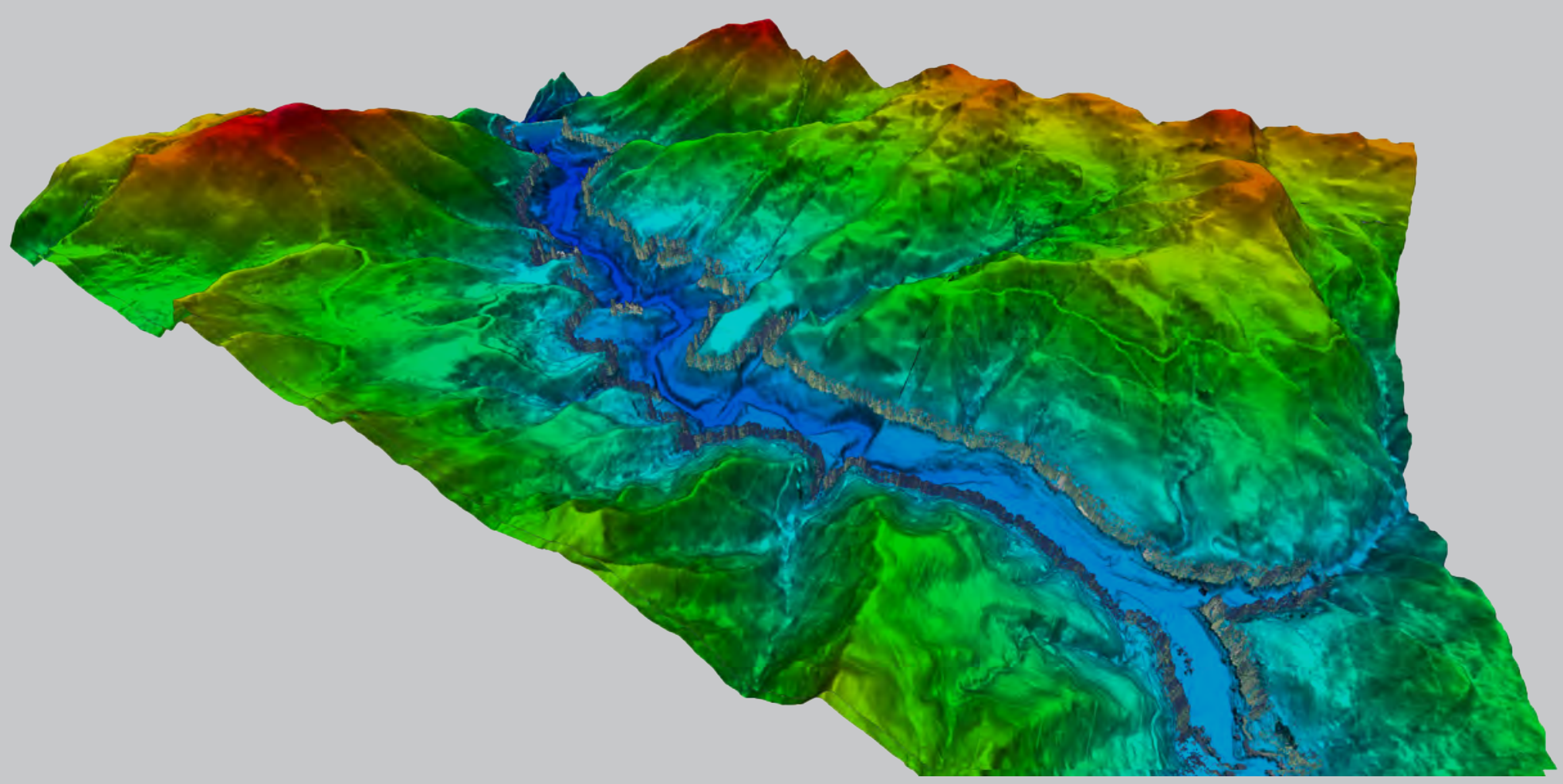

Scientific Investigations Report 2021-5081 
Cover: Bathymetric and terrestrial lidar results for Loch Lomond Reservoir, Calif. Bathymetric and lidar data are shown overlain and merged to U.S. Geological Survey 3DEP digital elevation model. Lidar data were pixelated with aerial imagery from the U.S. National Map Imagery (NAIP). 


\section{Storage Capacity and Sedimentation Characteristics of Loch Lomond Reservoir, California, 2019}

By Daniel R. Whealdon-Haught, Scott A. Wright, and Mathieu D. Marineau

Water Availability and Use Science Program

Prepared in cooperation with the city of Santa Cruz

Scientific Investigations Report 2021-5081 


\section{U.S. Geological Survey, Reston, Virginia: 2021}

For more information on the USGS - the Federal source for science about the Earth, its natural and living resources, natural hazards, and the environment—visit https://www.usgs.gov or call 1-888-ASK-USGS.

For an overview of USGS information products, including maps, imagery, and publications, visit https://store.usgs.gov/.

Any use of trade, firm, or product names is for descriptive purposes only and does not imply endorsement by the U.S. Government.

Although this information product, for the most part, is in the public domain, it also may contain copyrighted materials as noted in the text. Permission to reproduce copyrighted items must be secured from the copyright owner.

Suggested citation:

Whealdon-Haught, D.R., Wright, S.A., and Marineau, M.D., 2021, Storage capacity and sedimentation characteristics of Loch Lomond Reservoir, California, 2019: U.S. Geological Survey Scientific Investigations Report 2021-5081, 28 p., https://doi.org/10.3133/sir20215081

Associated data for this publication:

Whealdon-Haught, D.R., Wright, S.A., and Marineau, M., 2021, Loch Lomond Reservoir 2019 survey data:

U.S. Geological Survey data release, https://doi.org/10.5066/P91BUQWP.

ISSN 2328-0328 (online) 


\section{Acknowledgments}

We would like to acknowledge the city of Santa Cruz for funding this work, specifically

Ryan Bassett for his input and help. 



\section{Contents}

Acknowledgments ……...................................................................................................................

Abstract

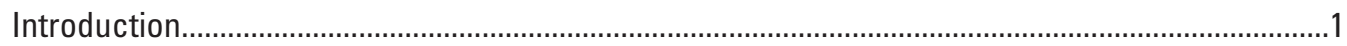

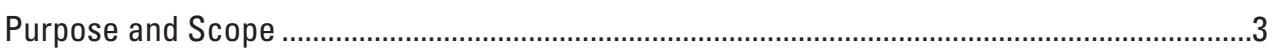

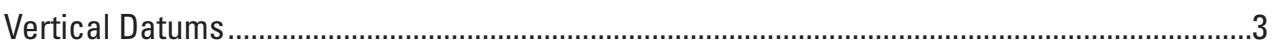

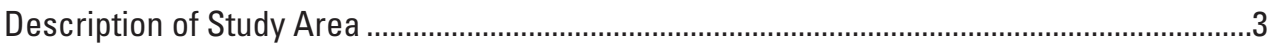

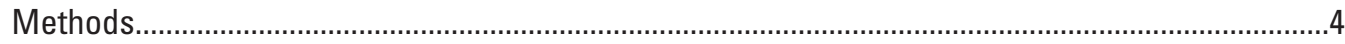

Bathymetry and Shoreline Topography Surveying................................................................

Digital Elevation Model and Storage-Volume Calculations .......................................................

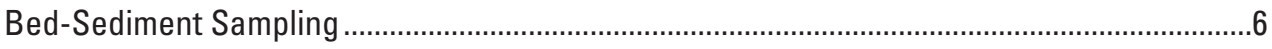

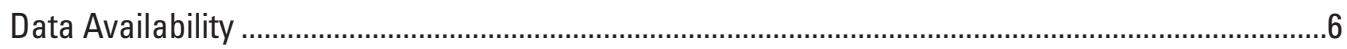

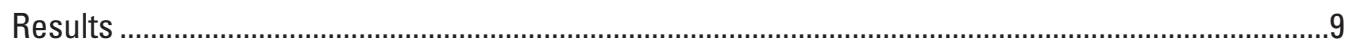

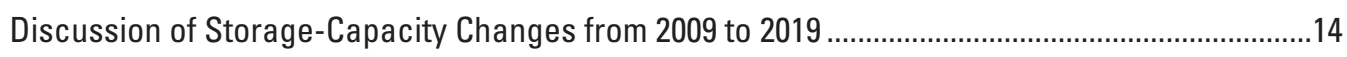

Discussion of Long-Term Reservoir Storage and Watershed Sediment Yield .................................19

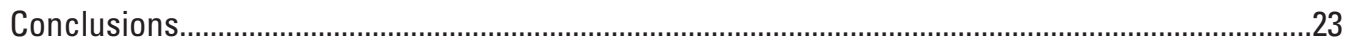

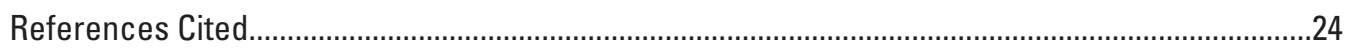

Appendix 1. Bowman and Williams 2012 Memo to the City of Santa Cruz ..................................25

Appendix 2. Bowman and Williams 2017 Memo to the City of Santa Cruz .....................................27

\section{Figures}

1. Map showing location of Loch Lomond Reservoir, Calif., and contributing watershed

2. Photograph showing the instrumentation set-up on May 29, 2019, at the Loch Lomond Reservoir boat ramp.........................................................................................

3. Photograph of the staff gage near the Loch Lomond Reservoir boat ramp on May 29, 2019, the first day of the survey.......................................................................

4. Map showing locations of bed-sediment samples and sound velocity profiles, Loch Lomond Reservoir, California, 2019 ....................................................................

5. Graph showing sound-velocity profiles from May 2019 survey at Loch Lomond Reservoir, California ...................................................................................................

6. Map showing the 1-square-meter digital elevation model from the May 2019 survey, Loch Lomond Reservoir, California ..

7. Map showing high-resolution DEM of the southern tip of the reservoir in the vicinity of the reservoir outlet works of Newell Creek Dam at Loch Lomond Reservoir, California, 2019.

8. Graph showing cumulative storage capacity as a function of water-surface elevation for 2019 survey of Loch Lomond Reservoir, California ..

9. Graph showing reservoir surface area as a function of water-surface elevation for 2019 survey of Loch Lomond Reservoir, California.

10. Graph showing bed-sediment composition as a function of distance upstream from the dam at Loch Lomond Reservoir, California. 
11. Map showing change in elevation between the 2019 and 2009 surveys at Loch Lomond Reservoir, California.

12. Graph showing change in storage between 2009 and 2019 in 2-ft elevation increments of Loch Lomond Reservoir, California

13. Histograms of elevation differences between 2009 and 2019 for Loch Lomond Reservoir, California, computed from differencing the 1-square-meter digital elevation models of the two surveys.

14. Graph showing daily reservoir water-surface elevation at Loch Lomond Reservoir, California, and daily mean flows at the San Lorenzo River at Big Trees streamgage for the period between the 2009 and 2019 surveys ...

15. Graph showing storage-capacity estimates from 2019 and all previous surveys as well as hindcasted storage capacities based on watershed sediment yields and reservoir characteristics, Loch Lomond Reservoir, California

\section{Tables}

1. Summary of independent elevation checks on the Sonar Lidar Mapping System............9

2. Hindcast results using regression models shown in figure 15

\section{Conversion Factors}

U.S. customary units to International System of Units

\begin{tabular}{|c|c|c|}
\hline Multiply & By & To obtain \\
\hline \multicolumn{3}{|c|}{ Length } \\
\hline inch (in.) & 2.54 & centimeter $(\mathrm{cm})$ \\
\hline inch (in.) & 25.4 & millimeter (mm) \\
\hline foot $(\mathrm{ft})$ & 0.3048 & meter $(\mathrm{m})$ \\
\hline mile (mi) & 1.609 & kilometer (km) \\
\hline mile, nautical (nmi) & 1.852 & kilometer $(\mathrm{km})$ \\
\hline \multicolumn{3}{|c|}{ Area } \\
\hline acre & 4,047 & square meter $\left(\mathrm{m}^{2}\right)$ \\
\hline acre & 0.004047 & square kilometer $\left(\mathrm{km}^{2}\right)$ \\
\hline square foot $\left(\mathrm{ft}^{2}\right)$ & 0.09290 & square meter $\left(\mathrm{m}^{2}\right)$ \\
\hline square mile $\left(\mathrm{mi}^{2}\right)$ & 2.590 & square kilometer $\left(\mathrm{km}^{2}\right)$ \\
\hline
\end{tabular}




\begin{tabular}{|c|c|c|}
\hline Multiply & By & To obtain \\
\hline \multicolumn{3}{|c|}{ Volume } \\
\hline cubic foot $\left(\mathrm{ft}^{3}\right)$ & 0.02832 & cubic meter $\left(\mathrm{m}^{3}\right)$ \\
\hline cubic yard $\left(\mathrm{yd}^{3}\right)$ & 0.7646 & cubic meter $\left(\mathrm{m}^{3}\right)$ \\
\hline acre-foot (acre-ft) & 1,233 & cubic meter $\left(\mathrm{m}^{3}\right)$ \\
\hline acre-foot (acre-ft) & 0.001233 & cubic hectometer $\left(\mathrm{hm}^{3}\right)$ \\
\hline \multicolumn{3}{|c|}{ Flow rate } \\
\hline acre-foot per day (acre-ft/d) & 0.01427 & cubic meter per second $\left(\mathrm{m}^{3} / \mathrm{s}\right)$ \\
\hline acre-foot per year (acre-ft/yr) & 1,233 & cubic meter per year $\left(\mathrm{m}^{3} / \mathrm{yr}\right)$ \\
\hline foot per second $(\mathrm{ft} / \mathrm{s})$ & 0.3048 & meter per second $(\mathrm{m} / \mathrm{s})$ \\
\hline cubic foot per second $\left(\mathrm{ft}^{3} / \mathrm{s}\right)$ & 0.02832 & cubic meter per second $\left(\mathrm{m}^{3} / \mathrm{s}\right)$ \\
\hline mile per hour $(\mathrm{mi} / \mathrm{h})$ & 1.609 & kilometer per hour $(\mathrm{km} / \mathrm{h})$ \\
\hline \multicolumn{3}{|c|}{ Mass } \\
\hline pound, avoirdupois (lb) & 0.4536 & kilogram $(\mathrm{kg})$ \\
\hline ton, short $(2,000 \mathrm{lb})$ & 0.9072 & metric ton $(\mathrm{t})$ \\
\hline ton, long $(2,240 \mathrm{lb})$ & 1.016 & metric ton $(\mathrm{t})$ \\
\hline \multicolumn{3}{|c|}{ Pressure } \\
\hline pound per square inch $\left(\mathrm{lb} / \mathrm{in}^{2}\right)$ & 6.895 & kilopascal (kPa) \\
\hline \multicolumn{3}{|c|}{ Density } \\
\hline pound per cubic foot $\left(\mathrm{lb} / \mathrm{ft}^{3}\right)$ & 16.02 & kilogram per cubic meter $\left(\mathrm{kg} / \mathrm{m}^{3}\right)$ \\
\hline \multicolumn{3}{|c|}{ Frequency } \\
\hline hertz $(\mathrm{Hz})$ & 1000 & kilohertz (kHz) \\
\hline \multicolumn{3}{|c|}{ Load } \\
\hline Tons per year per square mile $\left(\mathrm{t} / \mathrm{yr} / \mathrm{mi}^{2}\right)$ & 0.386102159 & Tons per year per square kilometer $\left(\mathrm{t} / \mathrm{yr} / \mathrm{km}^{2}\right)$ \\
\hline
\end{tabular}

\section{Datum}

Vertical coordinate information is referenced to the North American Vertical Datum of 1988 (NAVD 88).

Horizontal coordinate information is referenced to the North American Datum of 1983 (NAD 83).

Elevation, as used in this report, refers to distance above the vertical datum. 


\section{Abbreviations}

$\begin{array}{ll}\text { DEM } & \text { digital elevation model } \\ \text { DGPS } & \text { differential GPS } \\ \text { GNSS } & \text { global navigation satellite system } \\ \text { GPS } & \text { Global Positioning System } \\ \text { INS } & \text { inertial navigation system } \\ \text { lidar } & \text { light detection and ranging } \\ \text { NCDD } & \text { Newell Creek Dam Datum (local datum) } \\ \text { NOAA } & \text { National Oceanic and Atomospheric Admisistration } \\ \text { PosPac MMS } & \text { position correction service } \\ \text { PPK } & \text { post-processing kinematic } \\ \text { RTN } & \text { real-time cellular network } \\ \text { RTX } & \text { real-time satellite network } \\ \text { R10 } & \text { Trimble R10 rover } \\ \text { SLMS } & \text { sonar-lidar multibeam system } \\ \text { USGS } & \text { U.S. Geological Survey } \\ \text { WSE } & \text { water-surface elevation }\end{array}$




\title{
Storage Capacity and Sedimentation Characteristics of Loch Lomond Reservoir, California, 2019
}

\author{
By Daniel R. Whealdon-Haught, Scott A. Wright, and Mathieu D. Marineau
}

\section{Abstract}

In May of 2019, Loch Lomond Reservoir was surveyed by the U.S. Geological Survey (USGS) in cooperation with the city of Santa Cruz to assess the current storage capacity and sedimentation rates in the reservoir. Survey methods combined sonar soundings to measure bathymetry and lidar scans with GPS data to measure near-shore topography and sediment bed samples to understand reservoir bed-material size. The survey data produced a bare-earth digital elevation model (DEM) of the reservoir at a resolution of 1 square meter or better to elevations at or above the reservoir spillway elevation, providing the coverage needed to estimate storage capacity. Additionally, the USGS compared the current survey to storage estimates from historical surveys - particularly the most recent survey in 2009- to evaluate storage capacity trends. Lastly, a hindcast estimate of scaled sediment yield using sediment yields from the San Lorenzo River (USGS station 11160500) — where the San Lorenzo River watershed encompasses the Loch Lomond Reservoir watershed-were used to compare indirect estimates of storage loss to direct storage loss.

The 2019 survey resulted in a measured storage capacity of $8,770 \pm 50$ acre-feet. The differences in storage between 2009 and 2019 varied substantially by depth. In shallow areas with depths less than $30 \mathrm{ft}$ (at full reservoir), such as the very upstream end of the reservoir, storage loss (sediment deposition) dominated with a loss of about 68 acre-feet from 2009 to 2019. In areas deeper than $30 \mathrm{ft}$, persistent small storage gains over a wide range of depths totaled 82 acre-feet from 2009 to 2019.

Storage loss estimates derived from estimated watershed sediment yields and reservoir characteristics were similar to storage losses computed from past surveys. This hindcasting produced an estimate of about 500 acre-feet of total storage loss for the history of the reservoir, or an average of about 8-9 acre-feet/year during the 60 -year period. For the period
2009-2019, the hindcast produced an estimated total storage loss of 42 acre-feet, which is broadly consistent with the 68 acre-feet of storage loss computed for shallow areas based on the repeat surveys.

\section{Introduction}

Loch Lomond Reservoir, in Santa Cruz County, California, was created in 1960 through impoundment of Newell Creek by the Newell Creek Dam (fig. 1). The 182-foot-high dam allows the reservoir to store water for use by the city of Santa Cruz, which owns and operates the dam. Several surveys of the reservoir have been completed since the dam was constructed to assess changes in storage capacity due to reservoir sedimentation (Brown, 1973; Fogelman and Johnson, 1985; McPherson and Harmon, 2000; McPherson and others, 2011). McPherson and others (2011) presented an extensive review of the surveys completed prior to 2009, including developing error estimates for the previous surveys. The most recent survey in 2009 indicated a total reservoir storage capacity of 8,650 \pm 90 acre-feet (McPherson and others, 2011) and that the storage capacity had decreased by about 320 acre-feet since 1998. McPherson and Harmon (2000) estimated that storage-capacity increased between 1982 and 1998 by 141 acre-feet. In addition to storage estimates, McPherson and others (2011) also documented elevation increases along the reservoir thalweg on the order of 20-30 feet ( $\mathrm{ft}$ ) since dam construction, primarily in the upper reservoir and near the dam. In 2019, the U.S. Geological Survey (USGS), in cooperation with the city of Santa Cruz, completed a new reservoir survey to assess changes since 2009 and to provide information to the city of Santa Cruz for planned modifications to the dam inlet and outlet works. This report describes the results of the reservoir survey and provides further evaluation of changes in reservoir storage capacity through time. 


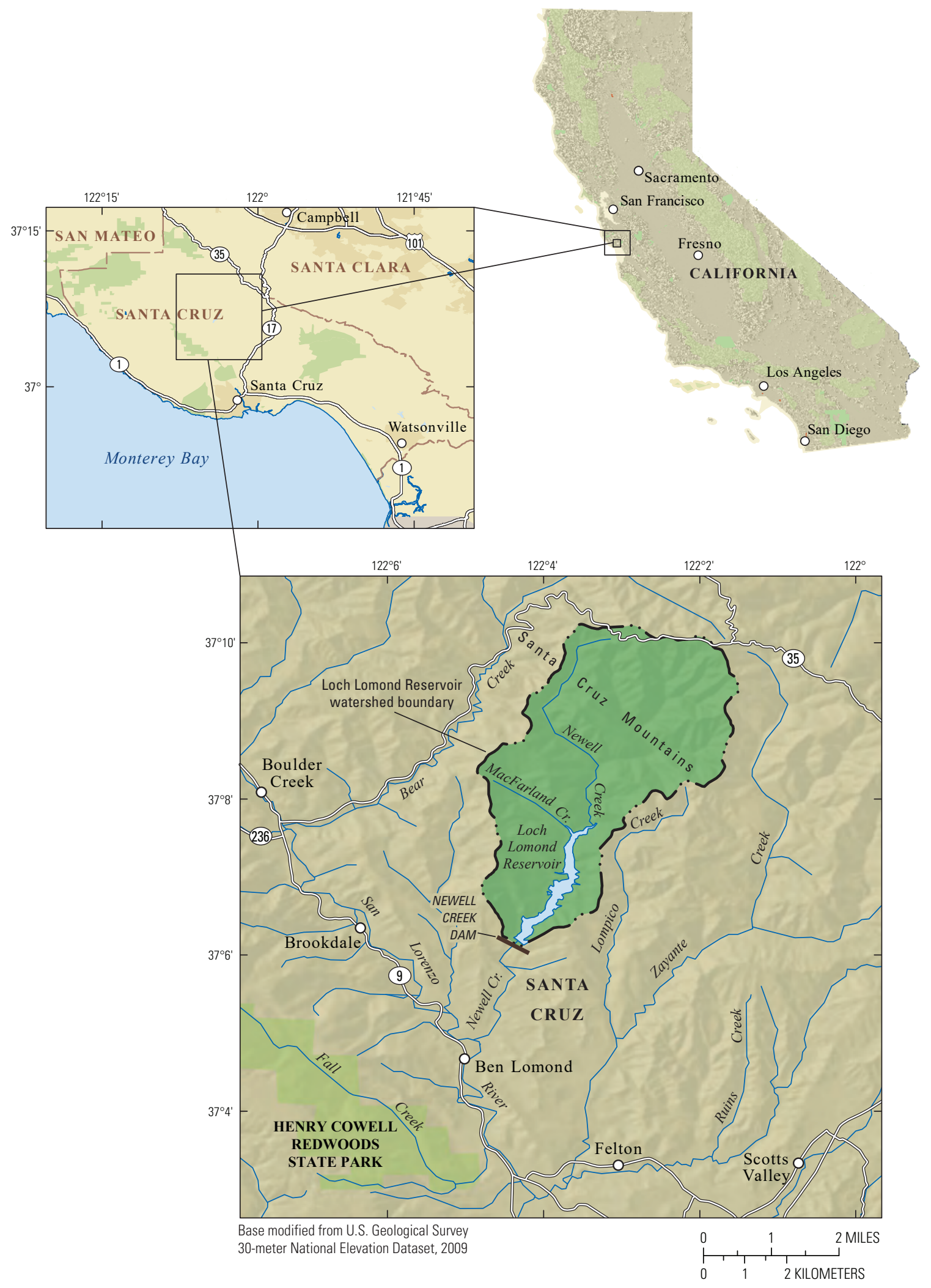

Figure 1. Location of Loch Lomond Reservoir, California, and contributing watershed. Reproduced from McPherson and others (2011). 


\section{Purpose and Scope}

Reservoirs slowly fill with sediment through time, reducing their storage capacity and potentially causing problems at outlet works (Morris and Fan, 1998; Schleiss and others, 2016). Thus, reservoir management requires up-to-date information about reservoir capacity as a function of reservoir water-surface elevation (WSE). This information can be obtained by surveying the bathymetry and shoreline topography of the reservoir. In addition, rates of sedimentation and loss of storage can be estimated by comparing new surveys with previous surveys, providing valuable information about the life of a reservoir and the appropriate frequency of future surveys. The primary purposes of this report were to (1) provide updated WSE-storage-capacity-surface-area curves for Loch Lomond Reservoir and (2) provide an assessment of sedimentation rates and the rate of storage-capacity loss through time.

\section{Vertical Datums}

Three vertical datums have been used for surveying work around Loch Lomond Reservoir: (1) the North American Vertical Datum of 1988 (NAVD 88), (2) the National Geodetic Vertical Datum of 1929 (NGVD 29), and (3) a local datum, referred to as the Newell Creek Dam Datum (NCDD; Bowman and Williams, appendixes 1 and 2), which was established during construction of the dam. Some earlier reports and engineering documents refer to this local datum as the "Santa Cruz Datum." There has been some confusion in the past as to whether the NCDD was equivalent to NGVD 29, and this was the assumption in McPherson and others (2011). In 2012, however, a differential leveling survey was done by Bowman and Williams (appendix 1), and it was determined that NCDD is not equivalent to NGVD 29. The leveling survey found that elevations referenced to NCDD are $0.962 \mathrm{ft}$ less than NGVD 29. Here, we primarily report elevations referenced to NAVD 88 and NCDD (Bowman and Williams, appendixes 1 and 2); the elevation difference between the two datums is $3.692 \mathrm{ft}$ (NCDD = NAVD 88-3.692). The elevation difference between NAVD 88 and NGVD 29 at Loch Lomond Reservoir is $2.730 \mathrm{ft}$ (NGVD $29=$ NAVD 88-2.730). The elevation offsets are from the Bowman and Williams 2012 memo (appendix 1) to the city of Santa Cruz, which is included as appendix 1 of this report. All elevation data collected or analyzed in this report are referenced to NAD 83 (2011) in the horizontal plane and to NAVD 88 Geoid 12b Epoch 2019.4 in the vertical direction. Conversion of datums was computed using the National Oceanic and Atmospheric Administration (NOAA) VDatum (v4.1) program (https://vdatum.noaa.gov/).

\section{Description of Study Area}

Loch Lomond Reservoir is in the Santa Cruz Mountains about 9.5 miles (mi) north of Santa Cruz, Calif. (fig. 1). The reservoir has two main tributaries, Newell Creek and MacFarland Creek, and the contributing watershed area is about 8.3 square miles $\left(\mathrm{mi}^{2}\right)$. Water can also be pumped into the reservoir from the San Lorenzo River downstream during dry periods when upstream runoff and reservoir storage are low. Maximum elevations in the watershed reach just over $2,300 \mathrm{ft}$, whereas the reservoir spillway is at an elevation of $580.87 \mathrm{ft}$ above NAVD 88 (577.18 ft above NCDD; appendix 1). The minimum elevation of the reservoir is $434 \mathrm{ft}$ above NAVD 88 . The dam initially had five outlets for releasing water at elevations ranging from 470 to $550 \mathrm{ft}$ above NCDD. In the summer of 2020, these outlets were replaced with three outlets at elevations of 480,500, and $530 \mathrm{ft}$ above NCDD.

The climate in the Santa Cruz Mountains is classified as Mediterranean, producing mild, wet winters and dry summers (McPherson and others, 2011). Mean annual precipitation in the watershed is about 30 inches, with substantial interannual variability. Peak-flow data from the USGS streamgage downstream from Loch Lomond Reservoir on the San Lorenzo River at Big Trees, Calif. (USGS station 11160500; U.S. Geological Survey, 2019), show that annual peak flows can vary from less than 1,000 cubic feet per second $\left(\mathrm{ft}^{3} / \mathrm{s}\right)$ to greater than 30,000 ft3 $3 / \mathrm{s}$ (December 1955 flood). The watershed is in a tectonically active region along the central California coast. The combination of high uplift rates and erodible marine sedimentary rocks makes the watershed susceptible to large landslides and substantial sediment loads during and following intense rainfall (East and others, 2018). 


\section{Methods}

The equipment and methods used to collect the topographic and bathymetric data and bed-sediment samples are similar to those described in Marineau and others (2020). The bathymetry and shoreline topography data were collected May 29-31, 2019; the bed-sediment samples and some additional survey points were collected on December 17 , 2019. The following equipment was used to collect the survey data (fig. 2):

- 19-ft Koffler aluminum boat with outboard jet motor

- Norbit iWBMS multibeam sonar system with integrated inertial navigation system (INS) Applanix Wavemaster 2 with global navigation satellite system (GNSS) receivers mounted above the multibeam transducer
- Norbit integrated light detection and ranging (lidar) built using Velodyne VL-16 scanner

- AML oceanographic base X2 profiler with an SV-Xchange ${ }^{\mathrm{TM}}$ sound-velocity sensor with integrated GPS

- Trimble R10 GNSS receiver with a 2-meter (m), fixed-length, carbon-fiber survey rod and Trimble TSC3 handheld controller

- US BMH-60 rotary-scoop bed-sediment sampler and cable reel

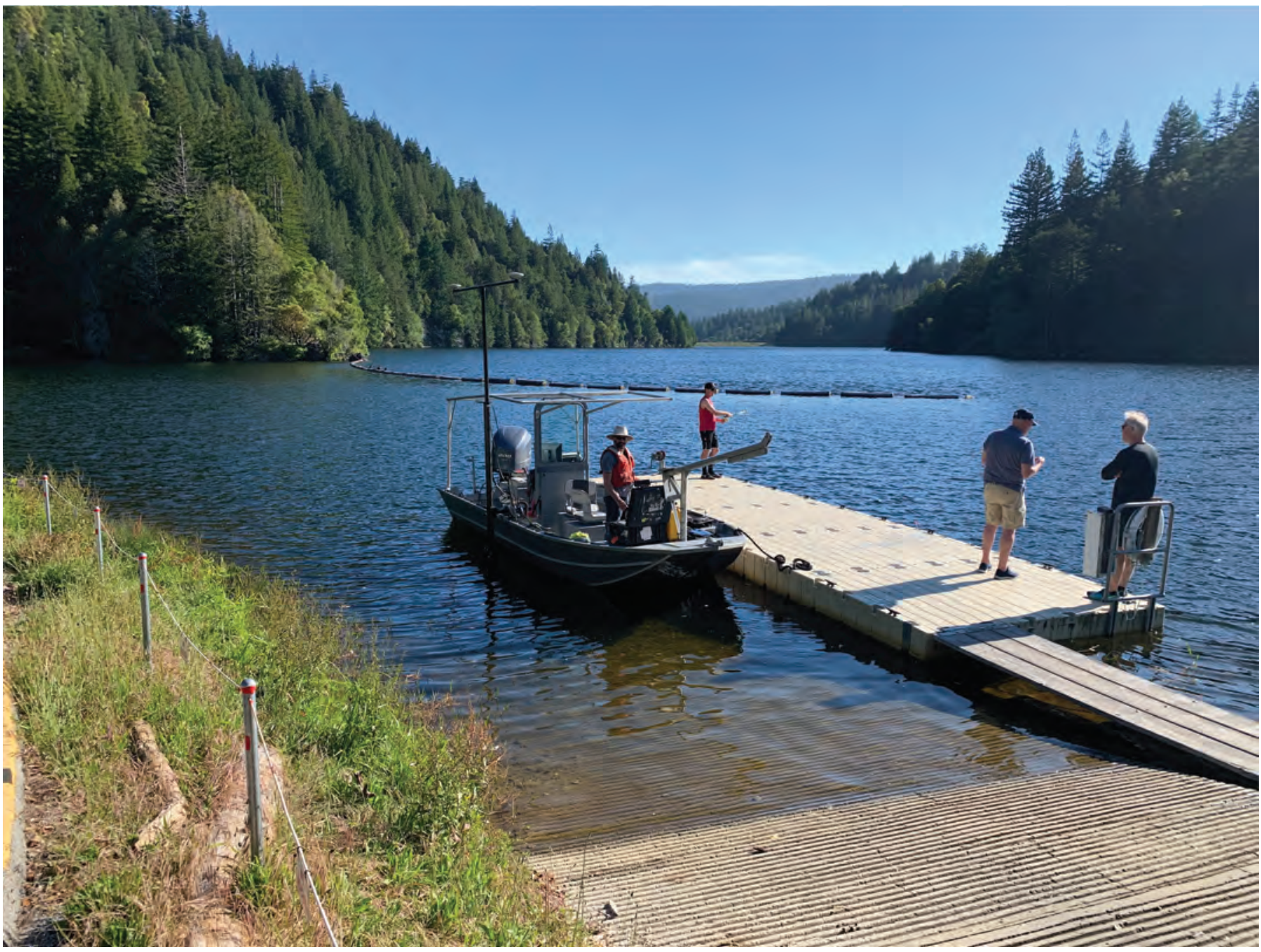

Figure 2. Instrumentation set-up on May 29, 2019, at the Loch Lomond Reservoir boat ramp. View is looking downstream, and Newell Creek Dam can be seen in the distance. 


\section{Bathymetry and Shoreline Topography Surveying}

Bathymetric data were collected using a boat-mounted Norbit iWBMS multibeam sonar system (referred to as a "multibeam"). The multibeam was attached to the side of the 19-ft aluminum Koffler motorized boat using a carbon fiber mount with pre-measured offsets (with respect to the INS) for all components provided by the manufacturer. The multibeam contains 512 beams, has a maximum swath width of 165 degrees (swath width during the survey ranged between 130 and 160 degrees), and was operated at 400 kilohertz $(\mathrm{kHz})$ frequency. Depth data (soundings) were typically recorded at 10 hertz $(\mathrm{Hz})$ with some variation because the ping rate automatically changes in response to environmental conditions. Two external GNSS receivers were mounted above the multibeam at known offsets to collect position and heading data. An integrated inertial motion sensor measured pitch, roll, and yaw to make geometric corrections to depth soundings. Sound-velocity profiles (SVPs) were collected with the AML Base X2 profiler throughout the reservoir to adjust the depth soundings for vertical gradients in sound speed induced by temperature stratification in the reservoir. Here, the entire data collection platform (multibeam sonar, lidar scanner, INS, sound speed sensor) is referred to as the sonar-lidar mapping system, or SLMS.

System checks, compass calibration (often referred to as a GNSS azimuth measurement system, or GAMS, calibration) and patch tests were done to ensure that the multibeam and INS were operating properly. The GAMS calibration process provides a heading alignment calibration and assessment of the offsets among all system components, whereas the patch test provides calibration of the pitch, heave, roll, and latency of the system. The patch tests consisted of collecting and processing swaths of overlapping bathymetric and shoreline topographic data. Bar checks were also carried out at multiple depths to ensure multibeam performance and to verify the tape down measurement of the sonar head draft. Raw bathymetric data were edited using the software program Qimera (https://www.qps.nl/qimera/). Data were first filtered using a strong spline routine followed by manual de-spiking as necessary. All obvious submerged aquatic vegetation was removed in order to obtain a sub-aqueous bare-earth surface from the multibeam.

Shoreline topographic data were collected with the Norbit integrated lidar scanner. The lidar unit was mounted above the multibeam on the same carbon-fiber pole and faced outward to the starboard side of the boat. The lidar was fully integrated into the system such that the INS calibration was the same as for the multibeam, with a separate patch test for the lidar data. The lidar scans in a 360-degree-vertical slice and has a range of approximately $230 \mathrm{ft}$. The shoreline topography was surveyed by circling the lake as closely as possible to the shoreline with the multibeam swath angle tilted toward the shore; this minimizes the gap at the water surface between the multibeam and lidar data. Raw lidar data were edited in Global Mapper 21 (https://www.bluemarblegeo.com/products/ global-mapper.php). Data were classified using the automated classification (https://www.bluemarblegeo.com/lidar-module/) routines to define ground, vegetation, buildings (for example, docks), and noise. This automated process creates a curved surface from a subset of the point cloud based on user input. A bin size of 2 square meters $\left(\mathrm{m}^{2}\right)$ was used for this work with a minimum height departure of $0.15 \mathrm{~m}$ and a maximum height delta of $10 \mathrm{~m}$, where the minimum departure height defines the accepted height change from the local average minimum used to classify the ground and the maximum height delta defines the expected range of ground-based elevation points. Lastly, the expected terrain slope varied between 5 and 35 degrees, based on the area of the reservoir. Once classified, ground lidar data were further filtered by finding the local minimum based on a 1.5 square foot $\left(\mathrm{ft}^{2}\right)$ area. The ground classified subset was then used as the subaerial bare-earth surface.

Post-processing kinematic (PPK) methods were applied after the survey to refine the INS data, providing centimeter-level accuracy for elevation and horizontal position of the INS, which because of the integrated system, further improves the bathymetry and lidar spatial resolution. The PPK methodology eliminates the need for traditional survey methods such as robotic total station tracking from known benchmarks or real-time kinematic GPS corrections. All bathymetric and topographic survey data were post-processed using PosPacMMS 8.4 PPK positioning service (https://www.applanix.com/products/ pospac-mms.htm), which incorporates all nearby continuously operating reference stations (CORS) to correct the trajectory of the survey path originally collected in differential GPS (DGPS). The solutions from PPK were evaluated using several independent measurements of elevation: (1) measurements of WSE and topographic points collected with the Trimble R10 GNSS receiver connected to a real-time network (RTN); (2) measurements of the WSE of the lake from the staff gage operated by the city of Santa Cruz (fig. 3; daily staff-gage readings provided by the city of Santa Cruz), and (3) measurements of the spillway elevation by Bowman and Williams (appendix 1). These comparisons were also used to develop an error estimate for the storage-capacity calculations, as described in the "Results" section. 


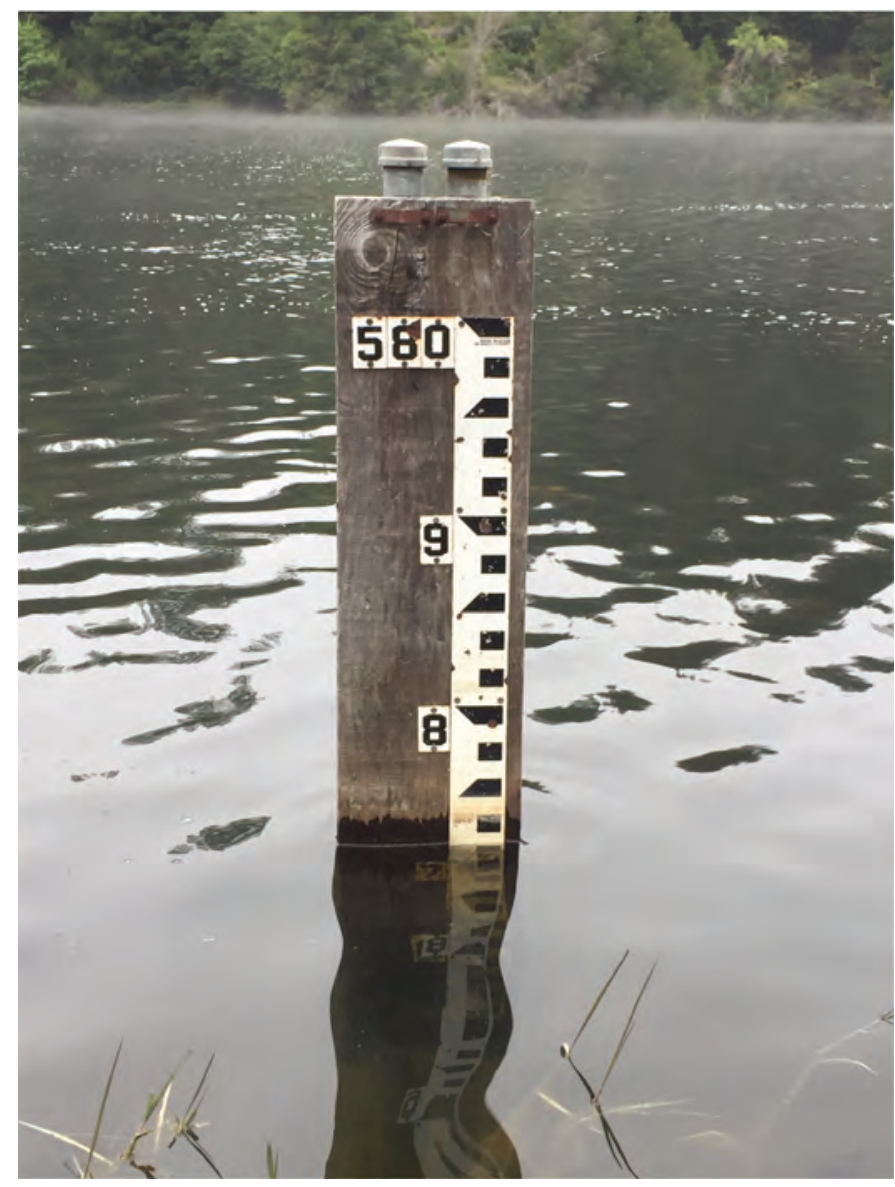

Figure 3. The staff gage near the Loch Lomond Reservoir boat ramp on May 29, 2019, the first day of the survey. Water-surface elevation was 577.20 feet Newell Creek Dam Datum and did not change during the survey.

\section{Digital Elevation Model and Storage-Volume Calculations}

Raw depth-sounding data were first automatically corrected for changes in sound velocity, pitch, roll, and heave in Qimera. Additionally, sound speed corrections were applied in both time and space using an automated application in Qimera. Bathymetric and lidar data were then converted from depth or height above the multibeam (the INS reference point) to elevation using the PPK trajectory data from the POSMMS corrections. The processed and filtered data were then merged and imported into ArcGIS (Environmental Systems Research Institute, Inc., 2017) as a point file.

A $1-\mathrm{m}^{2}$ resolution DEM was created in ArcGIS using a nearest neighbor interpolation algorithm at a $1-\mathrm{m}^{2}$ cell size. The elevation data from the DEM were then exported to MATLAB $^{\circledR}$ (MathWorks, Inc., 2018) to obtain the storage capacity and surface area of the reservoir at $0.1-\mathrm{ft}$ WSE increments. Using the 0.1 -ft WSE increments, storage for each $1-\mathrm{m}^{2}$ cell was computed by subtracting the WSE from the bed elevation for each cell at or below the WSE (that is, we excluded a cell with a bed elevation above the WSE increment). For all cells below the WSE, storage was determined by summing all the cells (in cubic meters) and converting to acre-feet. Surface area was computed in a similar manner and computed by finding all $1-\mathrm{m}^{2}$ cells at or below the WSE increment and summing (in $\mathrm{m}^{2}$ ) and converting to acres. DEM uncertainty was assessed by computing the difference between the DEM and independently measured survey points. Two sets of points were collected; the first set was collected during the survey (at the water surface), and the second set was collected post-survey at locations below the water surface during the survey. These independent checks assess the lidar and the bathymetry data with respect to the developed DEM.

\section{Bed-Sediment Sampling}

Bed-sediment samples were collected to assess the spatial variability of the bed-material size with respect to sedimentation. Bed sediment was sampled using a US BMH-60 rotary-scoop sampler following standard USGS protocols for use of these samplers (Edwards and Glysson, 1999). Rotary-scoop samplers are designed to collect material from the top 2 inches of the bed. Sediment samples were generally collected along the thalweg of the reservoir at the same locations as McPherson and others (2011), although not all locations were re-sampled. Navigation to the roughly 30 sampling locations (fig. 4; U.S. Geological Survey, 2019), as reported in McPherson and others (2011), was achieved using the boat's on-board GPS navigation system, which has an accuracy of about $8 \mathrm{ft}$ for horizontal positions.

Particle-size distributions were determined primarily by laser diffraction methods (Beckman Coulter LS 13320 particle size analyzer), which is applicable to particle sizes smaller than $1 \mathrm{~mm}$ in diameter; for particles greater than $1 \mathrm{~mm}$ in diameter sieving was used (Guy, 1969). All sample analyses were done in the USGS sediment lab in Sacramento, California. The methods for sample processing are described in detail in Marineau and others (2020) and Marineau and Wright (2017). Figure 4 shows the locations of the bed-sediment samples, and figure 5 shows the sound-velocity profiles; the bed-sediment site numbering is from McPherson and others (2011).

\section{Data Availability}

Data from this study are publicly available as a U.S. Geological Survey ScienceBase data release (Whealdon-Haught and others, 2021). The following results are provided: (1) 1- $\mathrm{m}^{2}$ DEM points file; (2) tables of storage capacity and surface area as a function of water-surface elevation at 0.1 -ft increments; (3) table of bed-sediment results; and (4) sound-velocity profiles. 


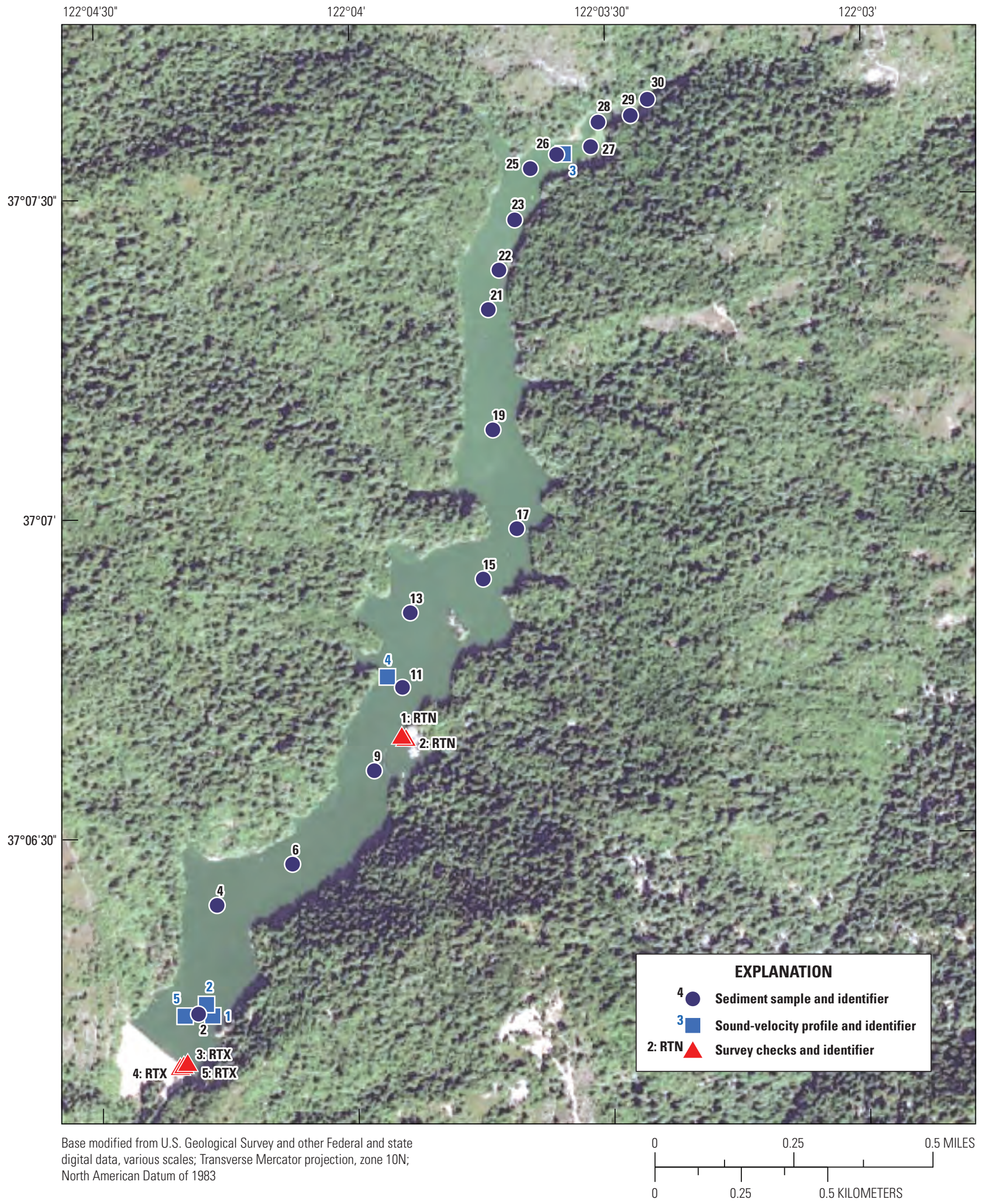

Figure 4. Locations of bed-sediment samples and sound-velocity profiles (SVPs), Loch Lomond Reservoir, California, 2019. The real-time cellular network (RTN) and real-time satellite network (RTX) points indicate the locations of survey points, and the SVP points indicate the locations of measured sound-velocity profiles. 


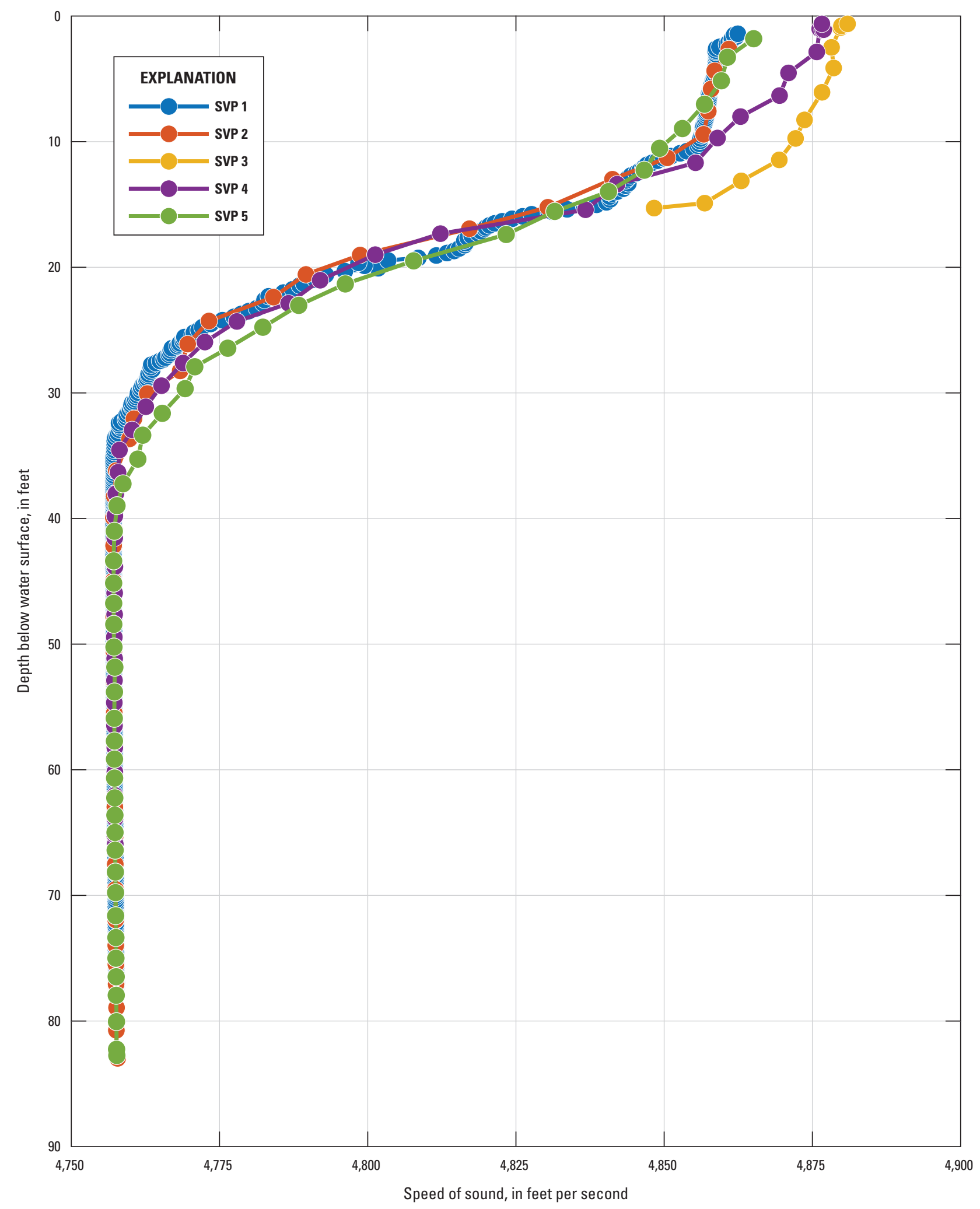

Figure 5. Sound-velocity profiles (SVPs; see figure 4 for locations) from May 2019 survey at Loch Lomond Reservoir, California. 


\section{Results}

Sound-speed profiles indicated differences in vertical structure, such that surface warming led to greater sound velocity near the surface and the presence of a well-defined thermocline in about the upper 30 feet of the water column.

Independent elevation measurements were in close agreement with elevations from the SLMS, as shown in table 1. Elevation differences ranged from -0.29 to $0.26 \mathrm{ft}$, with mean and median of signed differences equal to -0.08 and $-0.13 \mathrm{ft}$, respectively. The mean and median of the unsigned differences (absolute values) were 0.16 and $0.18 \mathrm{ft}$, respectively. These values were used to estimate the uncertainty in storage capacity, as described in the "Discussion of Storage-Capacity Changes from 2009 to 2019" section that follows. Here, we assumed the error from depth measurements by the SLMS was less than the error from the vertical resolution of the GNSS PosPac corrections to the INS.

Figure 6 shows the DEM from the survey $\left(1-\mathrm{m}^{2}\right.$ grid spacing) along with the spillway elevation contour. Figure 7 shows a higher resolution $\left(0.1-\mathrm{m}^{2}\right.$ grid spacing) DEM for the region around the existing outlet works at the time of survey, along with the elevation contours for the new outlets installed in the summer of 2020.

Figures 8 and 9 show the relations between water-surface elevation and reservoir-storage capacity and surface area for the 2019 survey. For the spillway elevation of $580.87 \mathrm{ft}$ above
NAVD 88 (577.18 ft above NCDD), the total storage capacity of the reservoir below the spillway crest elevation was 8,770 acre-feet, and the surface area at full pool was 168 acres. The dead storage (below the lowest outlet elevation of $480 \mathrm{ft}$ above NCDD) was 390 acre-feet, leaving 8,381 acre-feet of live (or usable) storage. The uncertainty in storage capacity was estimated by multiplying the largest difference between the SLMS and an independent elevation measurement from table $1(0.29 \mathrm{ft})$ by the total surface area at full pool (168 acre-feet), which equals 49 acre-feet $(0.6$ percent of total storage capacity); thus, the 2019 estimate of total storage capacity is $8,770 \pm 50$ acre-feet.

The results of the bed-sediment sampling are shown in figure 10, which indicates that the bed sediment in the reservoir (in the top 2 inches of the surface) is primarily composed of silt and clay sized particles, consistent with the findings of McPherson and others (2011) and Fogelman and Johnson (1985). At the very upstream end of the reservoir, the sediment is about 30-50-percent sand, but the sand content drops off quickly as the reservoir becomes deeper. The rapid downstream decrease in particle size is a common feature of depositional environments (Schleiss and others, 2016). One sample contained appreciable quantities of gravel-sized sediment, mid-way in the reservoir at site 17 in figure 4. Although it is not completely clear why gravel is exposed here, site 17 is in a narrow section of the reservoir with a tributary just upstream on river right that is a potential gravel source.

Table 1. Summary of independent elevation checks on the sonar-lidar mapping system (SLMS).

[ft, foot; NAVD 88, North American Vertical Datum of 1988; UTM, Universal Transverse Mercator; m, meter; GNSS, Global Navigation Satellite System; WSE, water-surface elevation; DEM, digital elevation model; N/A, not available; CSDS, California Survey and Drafting Supply; RTN, real-time network (cellular); RTX, real-time network (satellite)]

\begin{tabular}{|c|c|c|c|c|}
\hline Description of comparison & $\begin{array}{c}\text { Independent } \\
\text { elevation } \\
\text { (ft NAVD 88) }\end{array}$ & $\begin{array}{c}\text { SLMS } \\
\text { elevation } \\
\text { (ft NAVD 88) }\end{array}$ & $\begin{array}{l}\text { Difference } \\
\quad(\mathrm{ft})\end{array}$ & $\begin{array}{l}\text { UTM Northing, Easting } \\
\text { (m) of R10 GNSS points }\end{array}$ \\
\hline $\begin{array}{l}\text { GNSS }^{1} \text { WSE point \#1 near the boat ramp (May } 30 \text { ) versus SLMS } \\
\text { elevation from the } 1-\mathrm{m} \text { DEM }\end{array}$ & 580.78 & 580.59 & -0.19 & $4107586.015,583071.487$ \\
\hline $\begin{array}{l}\text { GNSS }{ }^{1} \text { WSE point \#2 near the boat ramp (May 30) versus SLMS } \\
\text { elevation from the } 1-\mathrm{m} \text { DEM }\end{array}$ & 580.71 & 580.58 & -0.13 & $4107586.017,583071.495$ \\
\hline $\begin{array}{l}\text { GNSS }^{2} \text { WSE point } \# 4 \text { at the dam (Dec. 17) versus SLMS elevation } \\
\text { from the } 1-\mathrm{m} \mathrm{DEM}\end{array}$ & 577.20 & 577.21 & 0.01 & $4106637.108,582425.035$ \\
\hline $\begin{array}{l}\mathrm{GNSS}^{2} \text { point } \# 5 \text { on the dam face (Dec. 17) versus SLMS elevation } \\
\text { from the } 1-\mathrm{m} \text { DEM }\end{array}$ & 581.45 & 581.71 & 0.26 & $4106637.089,582425.026$ \\
\hline
\end{tabular}

${ }^{1}$ Corrections from CSDS RTN.

${ }^{2}$ Corrections from RTX. 


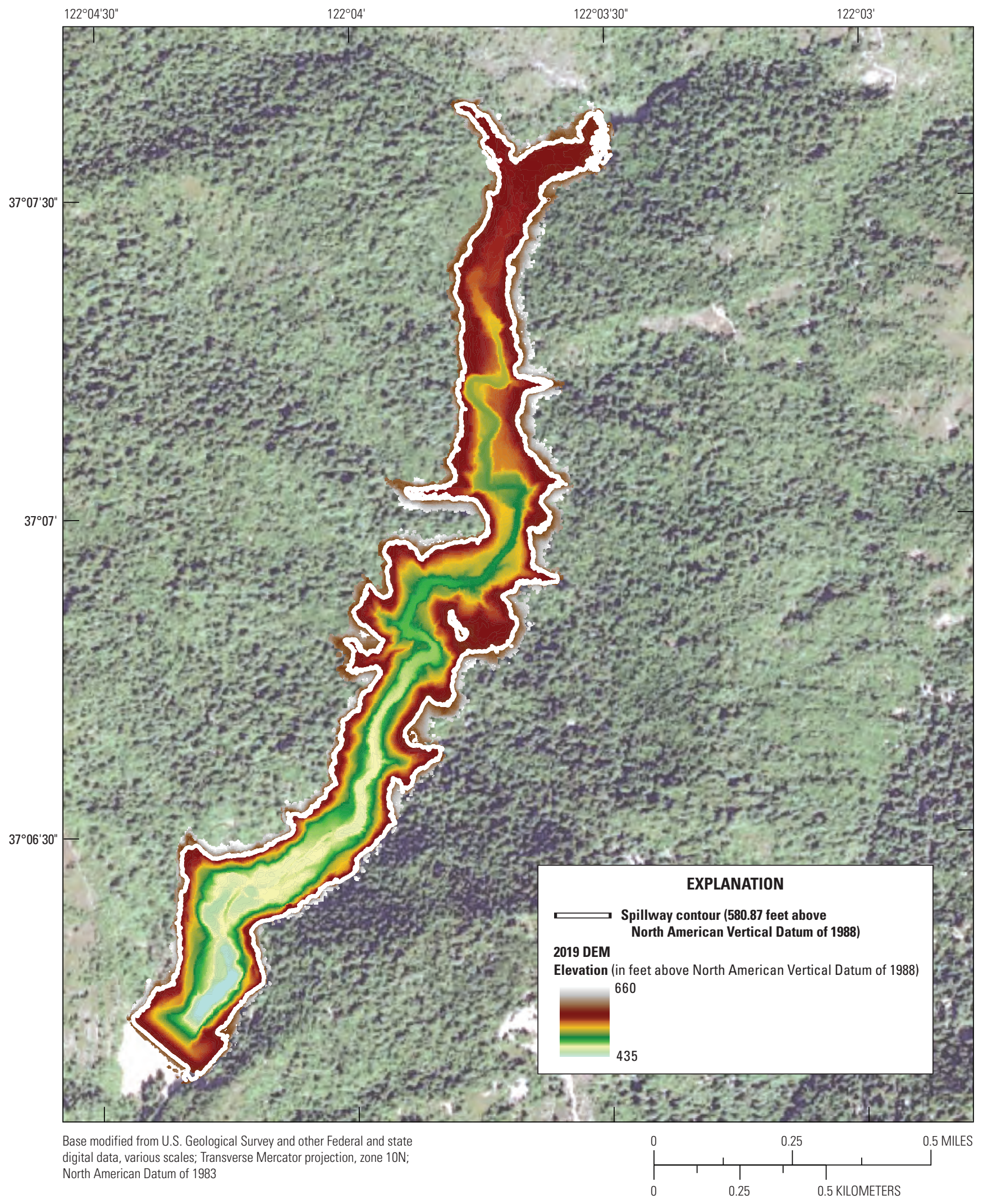

Figure 6. The 1-square-meter digital elevation model (DEM) from the May 2019 survey, Loch Lomond Reservoir, California. 


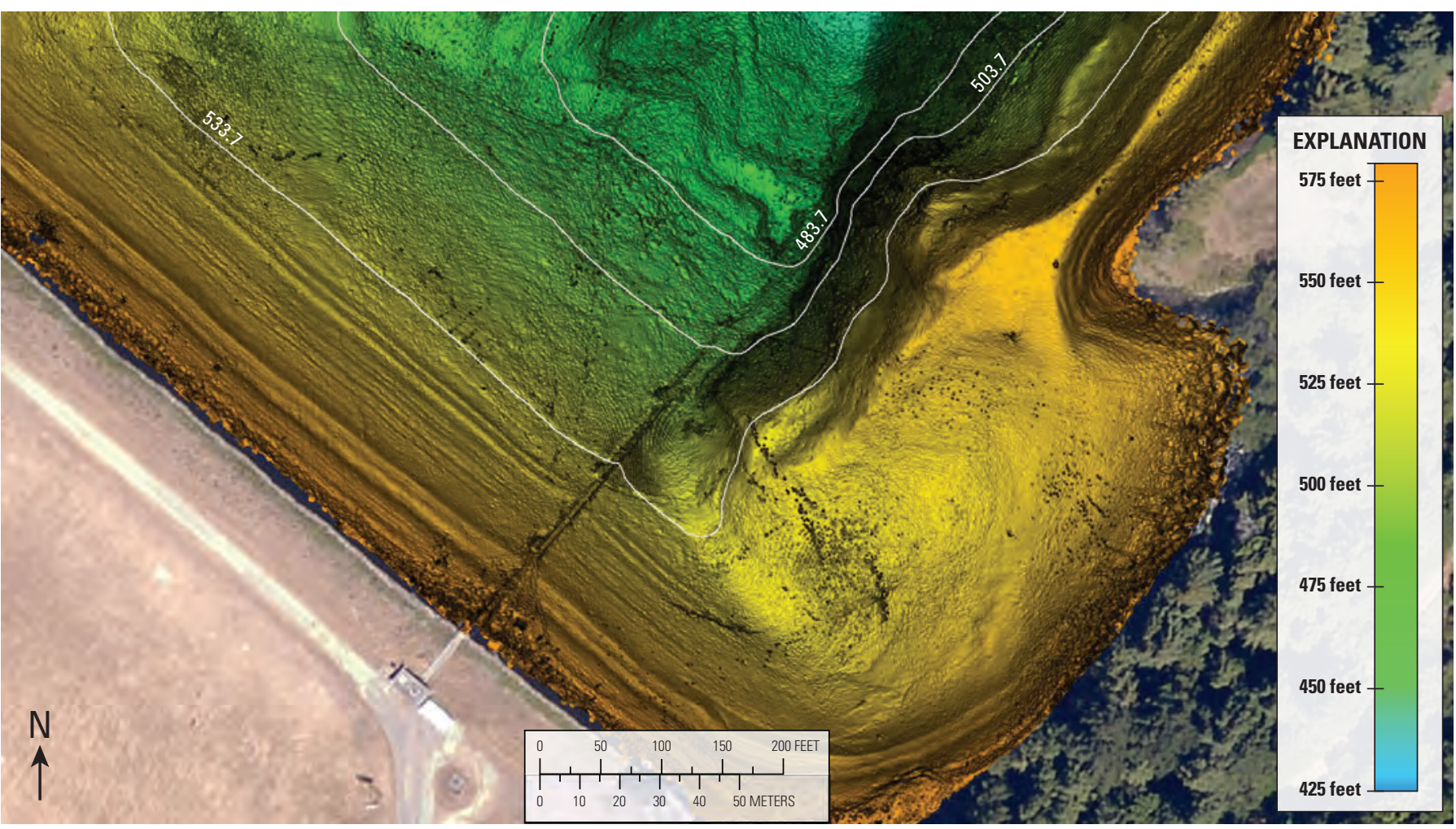

Figure 7. High-resolution (0.1-square meter) digital elevation model (DEM) of the southern tip of the reservoir in the vicinity of the reservoir outlet works of Newell Creek Dam at Loch Lomond Reservoir, California, 2019. Contours are for elevations (feet above the North American Vertical Datum of 1988) of the outlets installed in 2020. 


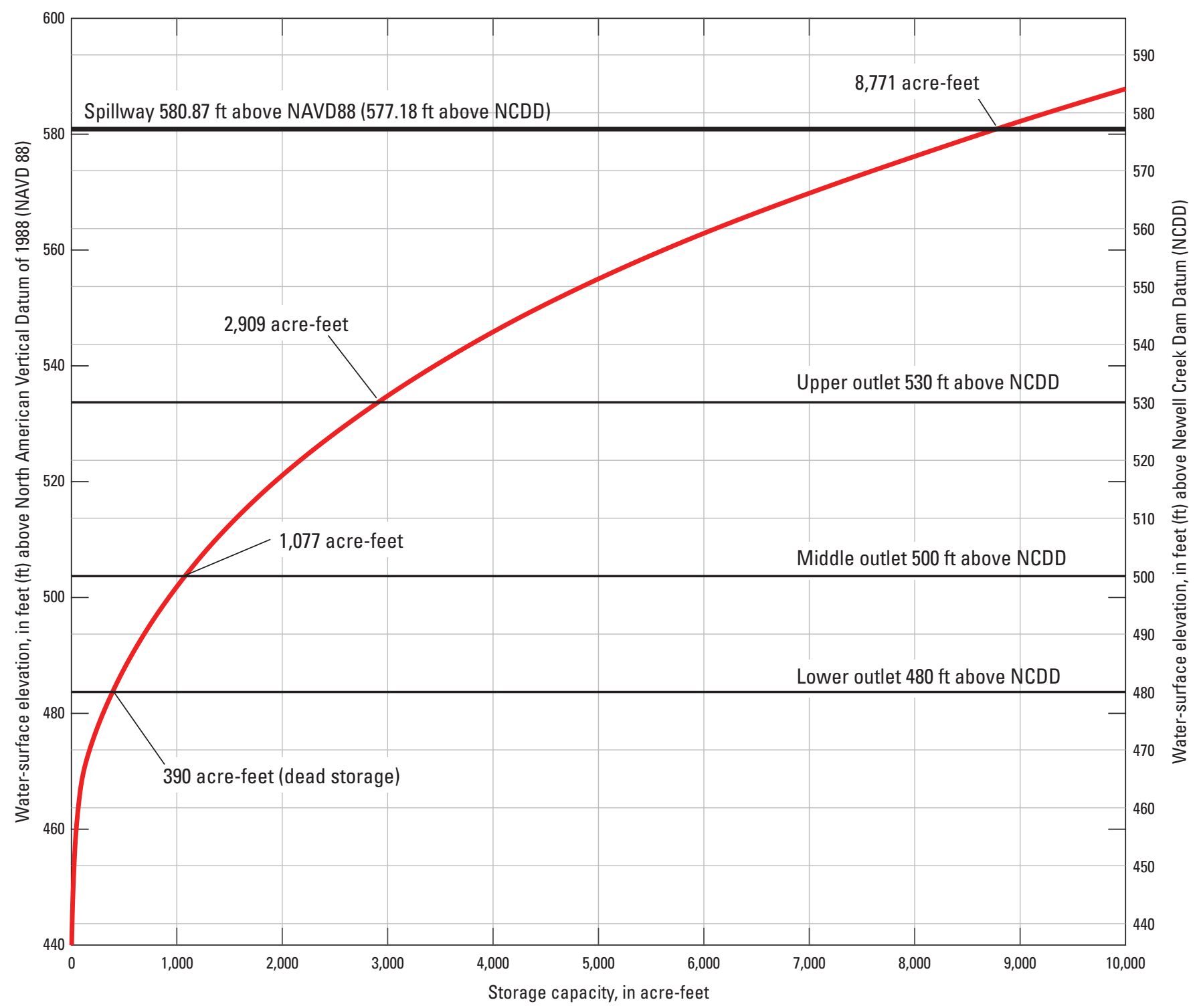

Figure 8. Cumulative storage capacity as a function of water-surface elevation for 2019 survey of Loch Lomond Reservoir, California. 


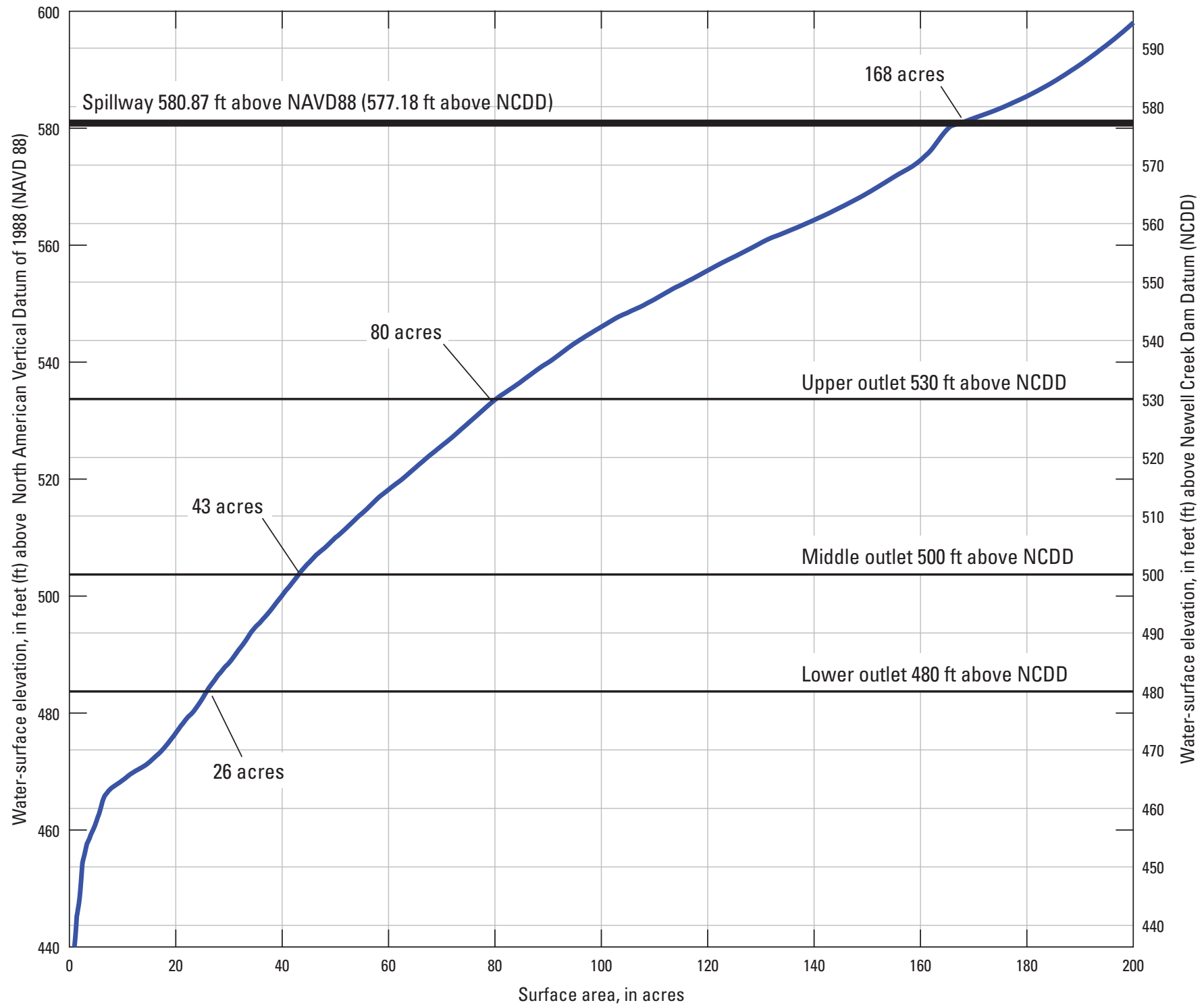

Figure 9. Reservoir surface area as a function of water-surface elevation for 2019 survey of Loch Lomond Reservoir, California. 


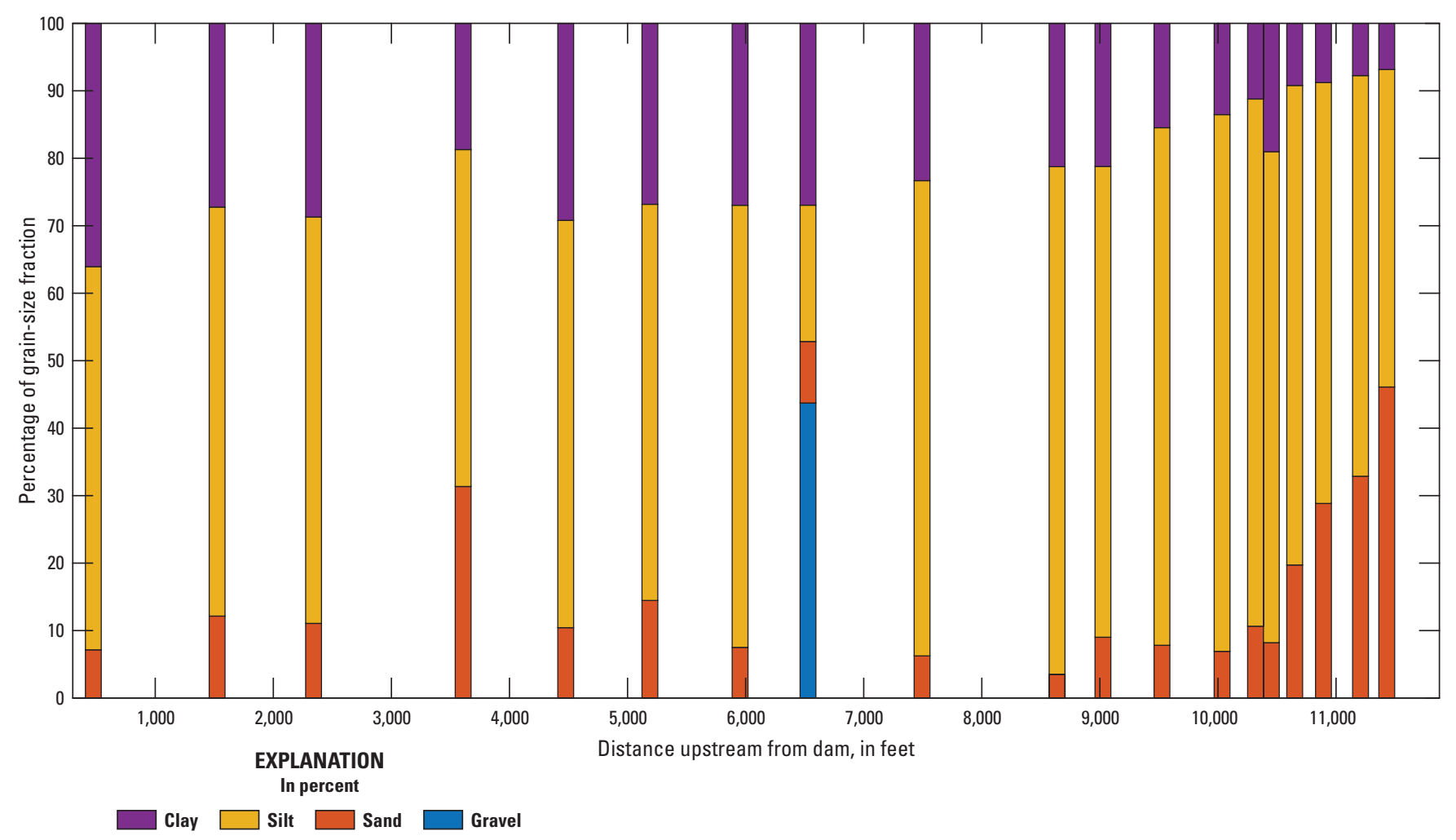

Figure 10. Bed-sediment composition as a function of distance upstream from the dam at Loch Lomond Reservoir, California.

\section{Discussion of Storage-Capacity Changes from 2009 to 2019}

The storage capacity measured in 2019 was $8,770 \pm 50$ acre-feet, which is 125 acre-feet, or 1.4 percent, greater than the published storage capacity from the 2009

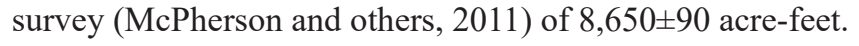
Although this amount of change is within the uncertainty bounds of the surveys (the upper bound of 2009 is slightly higher than the lower bound of 2019), a reservoir gaining storage capacity over time is counterintuitive and thus warrants further exploration.

One potential explanation for the difference in storage is that the elevation of the spillway used to compute the 2009 storage capacity was too low. A spillway elevation of $577.5 \mathrm{ft}$ NGVD 29 was used (McPherson and others, 2011) for the 2009 storage capacity calculation, but the leveling survey of Bowman and Williams (appendix 1) found the spillway elevation to be $578.14 \mathrm{ft}$ NGVD 29, a difference of 0.64 feet. Extension of the 2009 elevation-storage curve to this updated spillway elevation yields an additional 111 acre-feet of storage capacity, increasing the total estimate of storage capacity to 8,760 acre-feet. This revised estimate is nearly identical to the 2019 storage capacity (only 14 acre-feet less). This indicates that the change in total storage capacity between 2009 and 2019 was less than the uncertainty in the survey methods (similar methods were used for both surveys). Consideration of the spatial variability of change, however, as well as information on watershed sediment yields, can provide further context for interpreting the differences between 2009 and 2019, as described in the "Discussion of Long-Term Reservoir Storage and Watershed Sediment Yield" section that follows. The spillway elevation of $577.5 \mathrm{ft}$ NGVD 29 used in the 2009 survey also was used in the 1998 survey; however, the 1998 storage capacity was not revised here because the change based on the updated spillway elevation is much less than the storage uncertainty for that survey. Additionally, methods used in 1998 survey deviate from that of the 2009 and 2019 surveys.

Figure 11 shows the difference between the 2019 survey and the 2009 survey for overlapping areas. A positive value represents an increase in elevation since 2009. The results show that areas of deposition are in the upper reservoir, whereas the lower reservoir shows decreased elevation. Most of the reservoir shows elevation changes between -0.82 and $0.82 \mathrm{~m}$, which is similar to the range of error in our survey (table 1 and earlier discussion). Additionally, any datum inaccuracies from the 2009 survey using a lower reference benchmark for the survey could bias the differences toward negative elevation changes. 


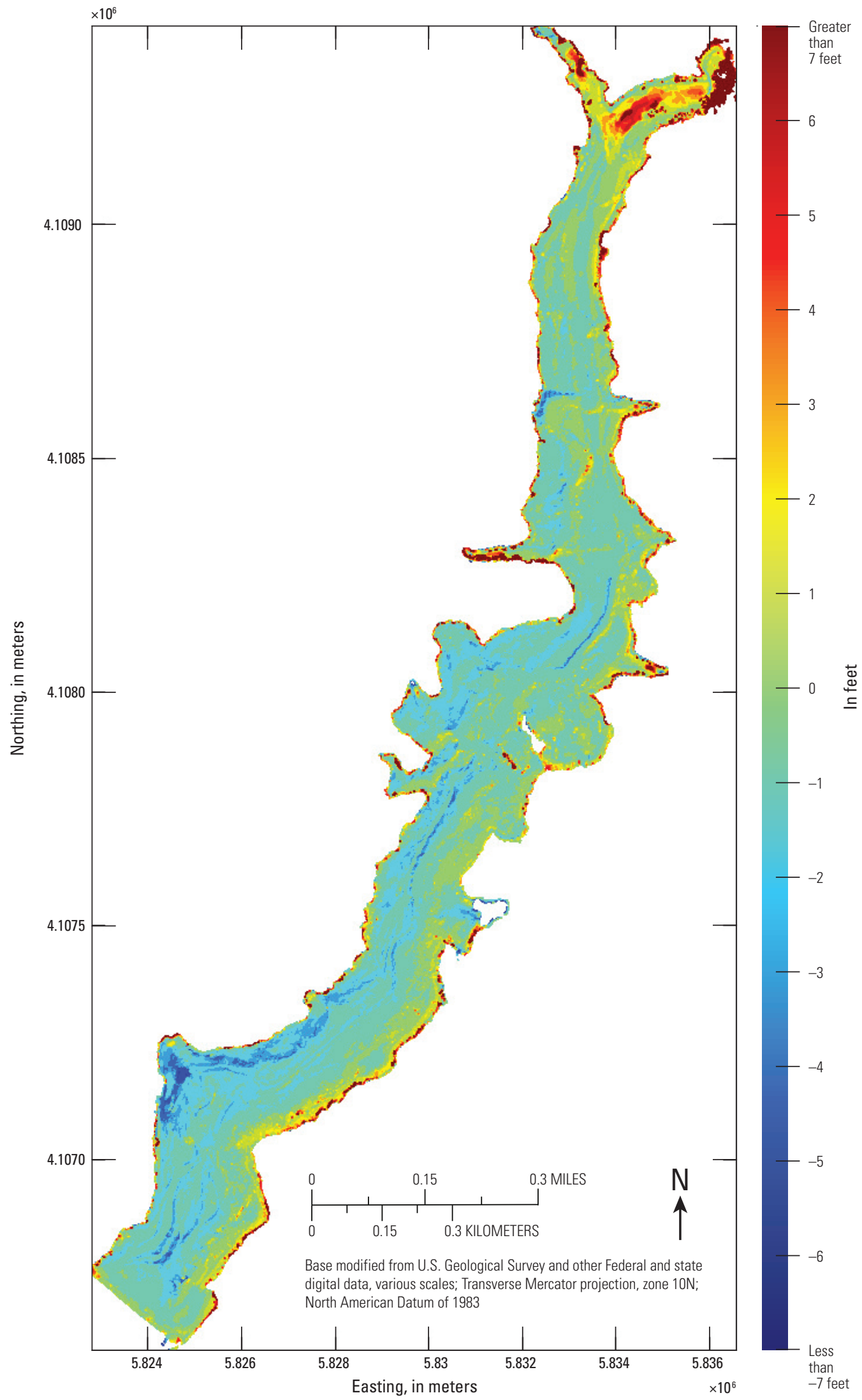

Figure 11. Change in elevation between the 2019 and 2009 surveys at Loch Lomond Reservoir, California; a positive value indicates an increase in elevation since 2009. 
The changes between 2009 and 2019 were further explored by examining the storage changes as a function of elevation. All previous surveys (1982, 1998, and 2009) documented sediment deposition at the upstream end of the reservoir, where depths are low and surface elevations are high (Fogelman and Johnson, 1985; McPherson and Harmon, 2000; McPherson and others, 2011; respectively). To compare changes as a function of depth or elevation, the WSE-storage curves for 2009 and 2019 were used to compute storage in 2-ft elevation increments (the increment from table 1 of McPherson and others, 2011), and the change in storage for each increment was computed. The results in figure 12 show that the change in storage was measurably different by depth. In shallow parts of the reservoir (depths less than about $30 \mathrm{ft}$ ), storage decreased from 2009 to 2019, indicating sediment deposition. In areas of the reservoir where depths exceeded $30 \mathrm{ft}$, small increases in storage were observed consistently over a wide range in depths. Although the storage losses in the shallow areas were greater per unit area, the area of deep water (110 acres) was much larger than the area of water less than $30 \mathrm{ft}$ deep ( 58 acres), resulting in a near balance between losses in the shallows and gains at depth. As shown in figure 12, the storage loss at depths less than $30 \mathrm{ft}$ was 68 acre-feet, whereas the storage gain at depths greater than $30 \mathrm{ft}$ was 82 acre-feet, resulting in the 14 acre-feet total storage increase between 2009 and 2019 noted previously. The average vertical changes computed from the volume change and the area of reach region were $+1.2 \mathrm{ft}$ in shallow areas and $-0.75 \mathrm{ft}$ in deep areas.

Differences in storage between 2009 and 2019 surveys are further explicated in figure 13, which shows histograms of elevation changes based on differences between $1-\mathrm{m}^{2}$ DEMs for the shallow and deep areas (positive elevation change indicates deposition). For the shallow areas, the mean and median differences were small and slightly negative $(-0.01$ and $-0.39 \mathrm{ft}$, repectively), but the large elevation differences in the upper reservoir were apparent in the right-tail of the distribution. For the deep areas, there were very few positive differences (deposition), and the mean $(-1.3 \mathrm{ft})$ and median $(-1.1 \mathrm{ft})$ values both indicated decreasing elevations between 2009 and 2019.

At least two possible reasons exist to explain the unexpected storage increases in deep areas of the reservoir: (1) surveying error in the vertical measurements and (2) consolidation of deposited sediment over time. With respect to surveying error, the mean and median differences in the deep areas were both about $1 \mathrm{ft}$, which is greater than the average vertical survey error reported for the 2009 and 2019 surveys of less than about $0.5 \mathrm{ft}$. Given the similar magnitude of the changes and the survey errors, the possibility that the storage changes in deep areas are a result of survey error should not be ruled out. A second possibility is that the consolidation of deposited sediment is gradually lowering bed elevations over time. Consolidation is a process known to occur in reservoirs over long periods (Morris and others, 2008), whereby the bulk density of the deposited sediment increases over time. Consolidation is greatest when the deposited sediment is silt- and clay-sized (Lara and Pemberton, 1963), such as in Loch Lomond Reservoir (particularly in the deeper areas closer to the dam; fig. 11). Thus, one potential interpretation of the increased storage (for deep areas but also just slightly for shallow areas) is that consolidation is gradually lowering bed elevations, and the consolidation rate is greater in deep areas, where the deposited sediment is the finest. This interpretation should be considered speculative because the survey error hypothesis is also very probable. Further investigation of the reservoir deposits, such as by coring in order to assess the vertical variability in bulk density, could help resolve this issue. 


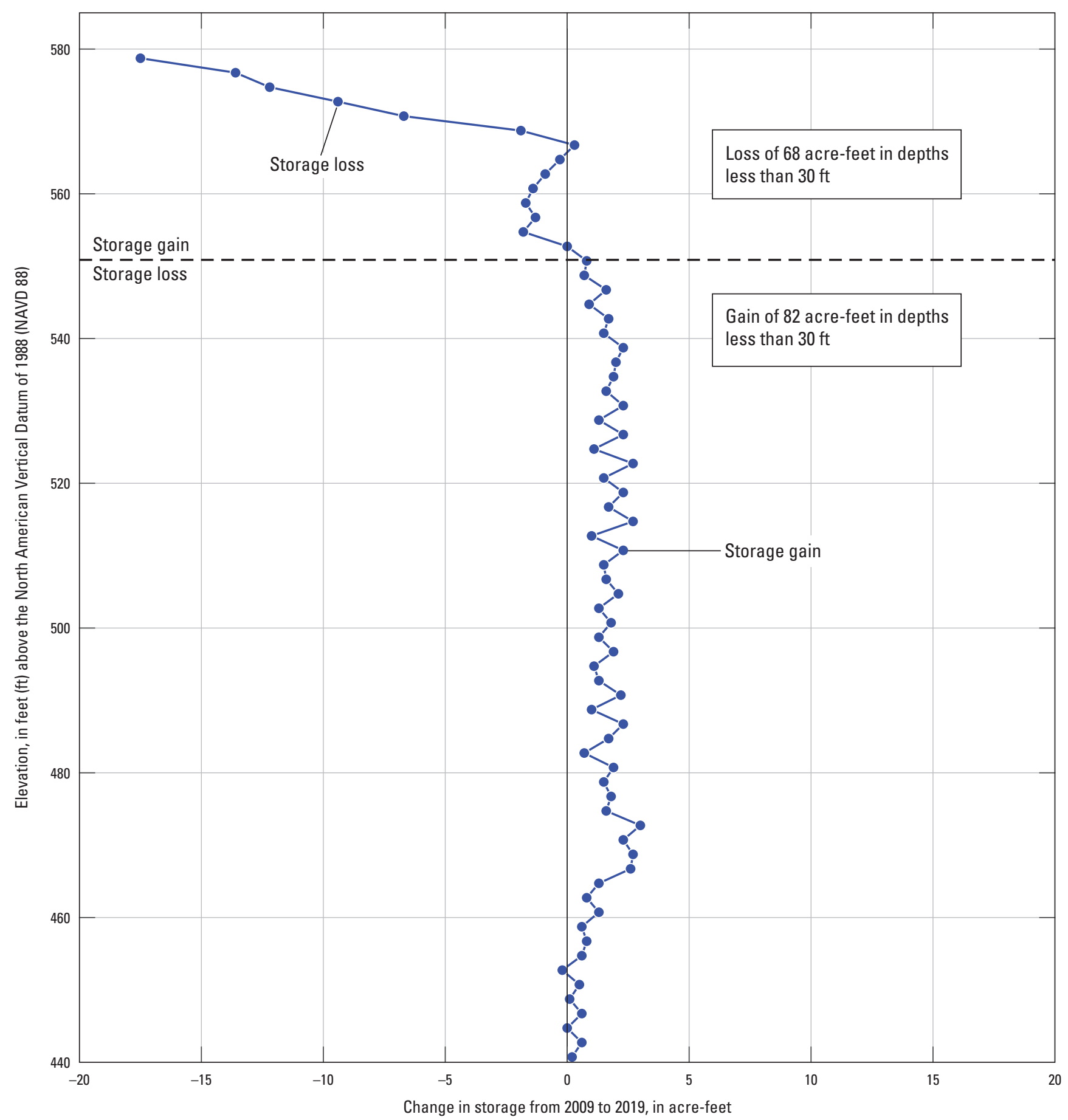

Figure 12. Change in storage between 2009 and 2019 in 2-foot elevation increments of Loch Lomond Reservoir, California. 
$\boldsymbol{A}$

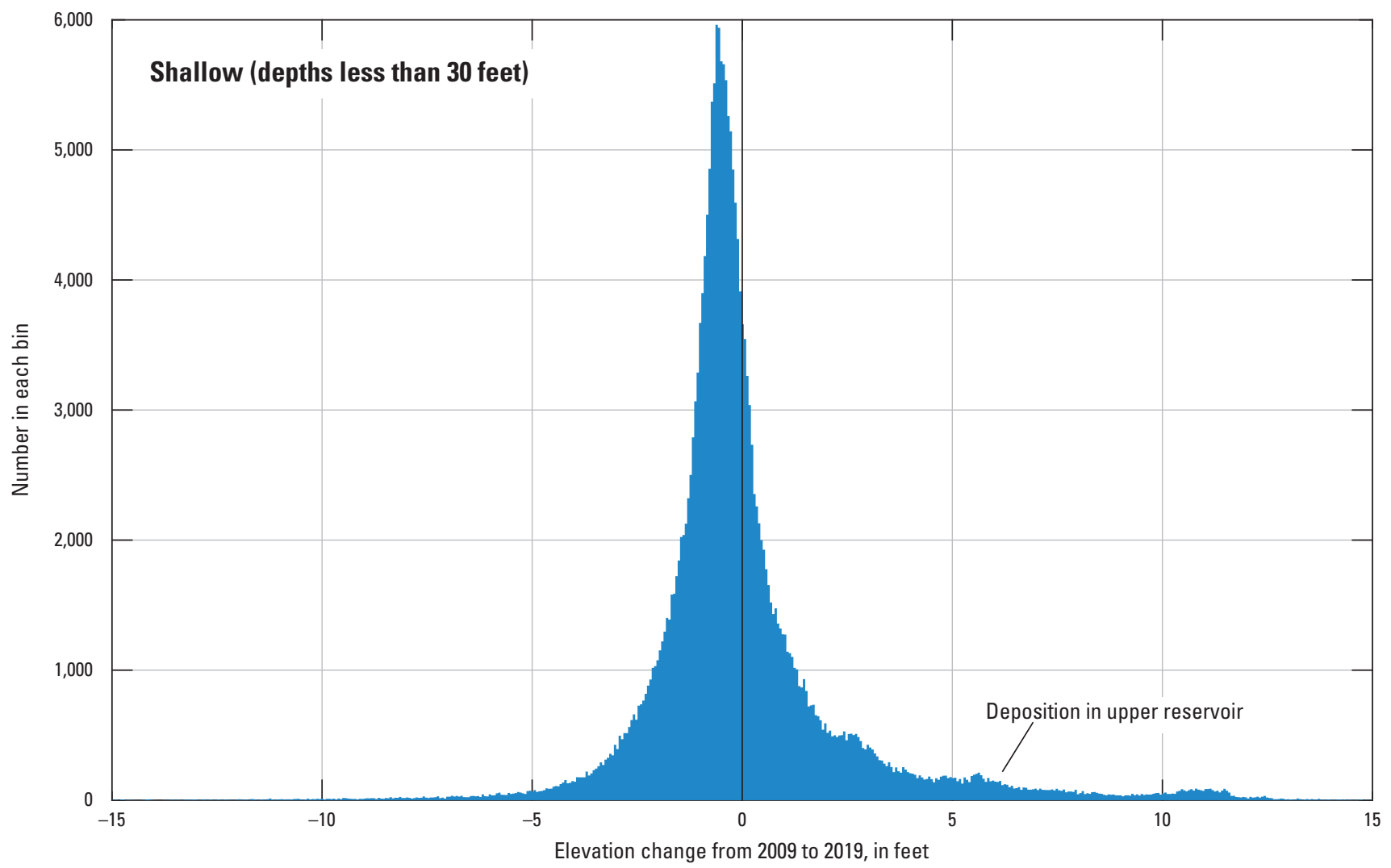

$\boldsymbol{B}$

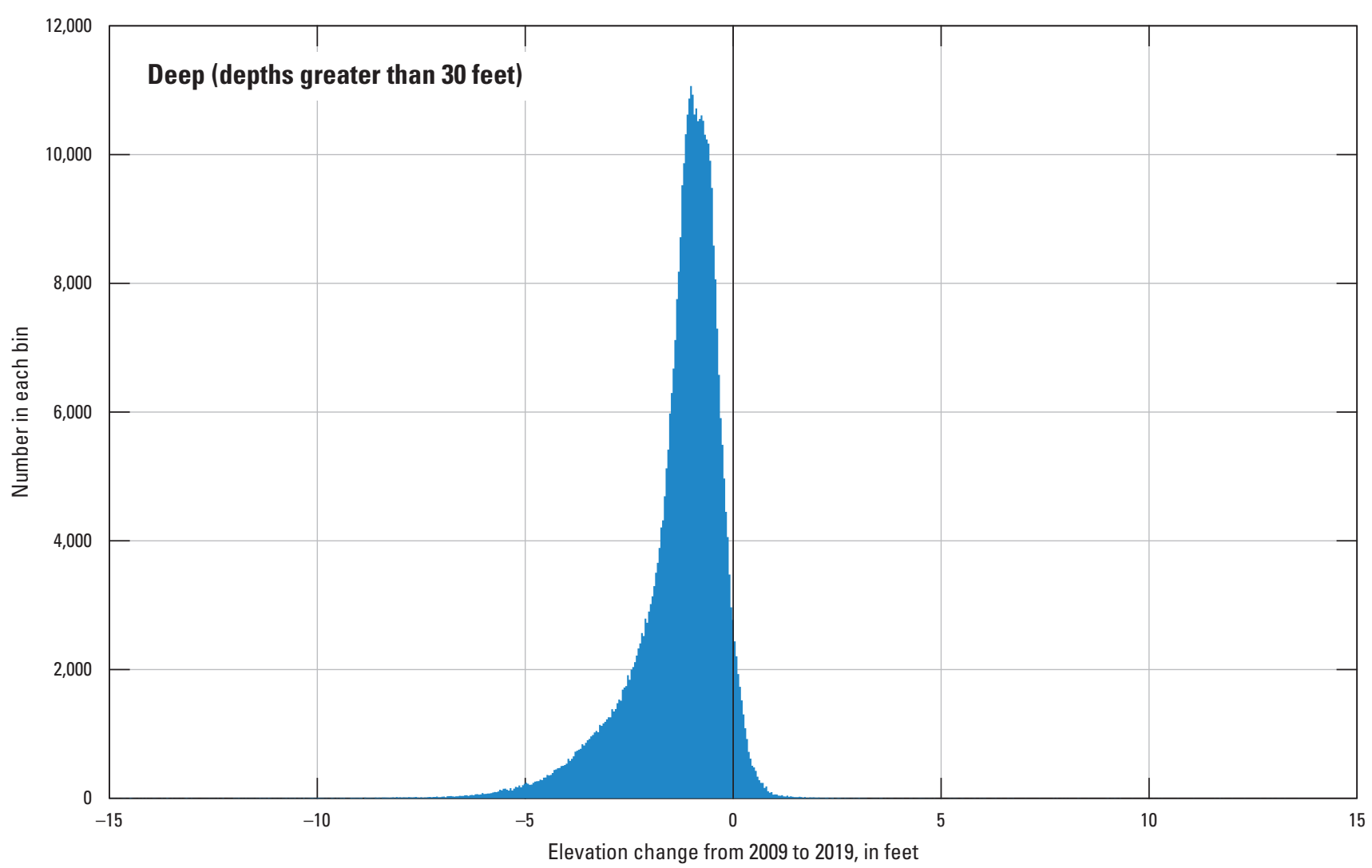

Figure 13. Elevation differences between 2009 and 2019 for Loch Lomond Reservoir, California, computed from differences in 1 -square-meter digital elevation models (DEMs) of the two surveys between $A$, shallow and $B$, deep areas. 


\section{Discussion of Long-Term Reservoir Storage and Watershed Sediment Yield}

Two methods can be used to compute storage losses in a reservoir: (1) directly as the difference in storage between two surveys, as detailed earlier for 2009 to 2019 , and (2) indirectly from information about sediment inflows to the reservoir, deposit density, and reservoir trap efficiency. The direct method is more comprehensive when modern methods have been used for the repeat surveys. As noted in McPherson and others (2011), however, older surveys can have substantial uncertainty that often precludes meaningful storage-change assessments. The indirect method can provide context for interpreting the direct storage-change calculations, particularly for older surveys, depending on the information available about watershed sediment yield and reservoir sediment.

To assess sediment yields delivered to the Loch Lomond Reservoir, the USGS scaled sediment yields in the San Lorenzo River watershed to that of the Loch Lomond
Reservoir. The period from 2009 to 2019 was reasonably similar to the period of record hydrologically. The mean flow at the San Lorenzo River at Big Trees streamgage (USGS station 11160500) for the entire period of record (1936-2019) was 131 cubic feet per second $(\mathrm{ft} / \mathrm{s})$; the mean flow for 2009-19 was $121 \mathrm{ft}^{3} / \mathrm{s}$ but included the highest single-year mean flow of $405 \mathrm{ft}^{3} / \mathrm{s}$ in 2017 (U.S. Geological Survey, 2019). Although the highest mean flow on record was during 2017, the 2017 peak flow of $19,000 \mathrm{ft}^{3} / \mathrm{s}$ is only the sixth highest on record and was substantially less than the historic peaks during December $1955\left(30,400 \mathrm{ft}^{3} / \mathrm{s}\right)$ and January $1982\left(29,700 \mathrm{ft}^{3} / \mathrm{s}\right)$. Daily reservoir WSEs and daily flows at the Big Trees streamgage for the period 2009-19 are shown in figure 14, illustrating the effects of low inflows during 2014-15 as well as the spilling events during wet years, particularly in 2017. There was at least one notable runoff event (2017) between the surveys that may have delivered substantial sediment from the watershed to the reservoir, causing decreased storage capacity.

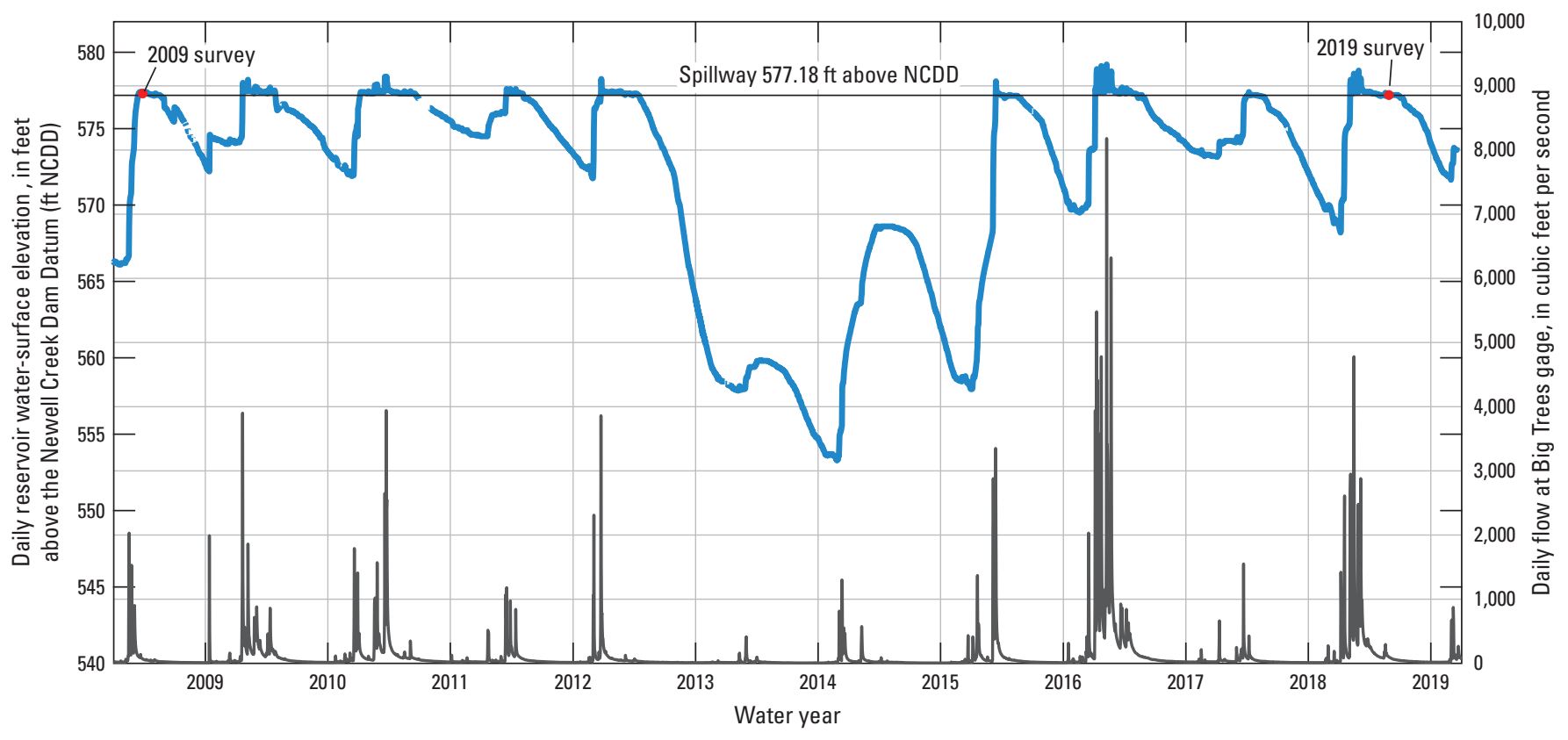

Figure 14. Daily water-surface elevation (WSE; blue line) at Loch Lomond Reservoir, California, and daily mean flows (black line) at the San Lorenzo River at Big Trees streamgage (U.S. Geological Survey station 11160500; U.S. Geological Survey, 2019) for the period between the 2009 and 2019 surveys. X-axis grid lines are October 1 . 
Estimates of annual sediment yields available for the San Lorenzo River are based on measurements of suspended-sediment loads at the USGS streamgages at Big Trees and Santa Cruz (USGS stations 11160500 and 11161000, respectively; U.S. Geological Survey, 2019) and represent two time spans: 1973-82 (Best and Griggs, 1991) and 2009-17 (Conaway and others, 2013; East and others, 2018). The earlier period is generally considered to have had higher sediment yields than the more recent period, reflecting anthropogenic activities and the effects of the 1982 flood in the record (East and others, 2018). If it is assumed that the watershed-sediment yields for the San Lorenzo River can be scaled by the Loch Lomond Reservoir drainage area to estimate sediment inflows to the reservoir, the storage loss in the reservoir can be computed from the following equation:

$$
S L=Y_{s} A_{L L} \frac{T}{D \times 100}
$$

where

\begin{tabular}{|c|c|}
\hline$S L$ & is the storage loss (volume/time), \\
\hline$Y_{s}$ & is watershed sediment yield (mass/time/area), \\
\hline$A_{L L}$ & $\begin{array}{l}\text { is the drainage area to Loch Lomond } \\
\text { Reservoir }\left(8.3 \mathrm{mi}^{2}\right)\end{array}$ \\
\hline$D$ & $\begin{array}{l}\text { is the bulk density (or specific weight) of } \\
\text { the reservoir sediment deposit (mass/ } \\
\text { volume), and }\end{array}$ \\
\hline & is the trap efficiency of the reservoir (percent). \\
\hline
\end{tabular}

Estimates of $D$ and $T$ are necessary in order to estimate storage loss from watershed sediment yields. Equation 1 does not account for the effects of consolidation of deposited sediment when the bulk density is held constant through time, which was the approach used for this study.

The inherent assumptions with this method are that the yields from San Lorenzo River represent that of Loch Lomond Reservoir and that the Loch Lomond Reservoir does not influence downstream yields. Loch Lomond Reservoir is of the same geology, vegetation, and topography as that of the larger, surrounding San Lorenzo River watershed, which indicates that samples from the San Lorenzo River should be representative. Nevertheless, we use a large uncertainty envelope to account for any unknown bias in our assumption. Lastly, because Loch Lomond Reservoir watershed is so small relative to San Lorenzo River watershed (approximately 6 percent), it seems safe to assume that downstream influence on sediment yields is minimal.
Bulk density was computed from the Lara and Pemberton (1963) method using the sediment-size fractions from the bed-sediment sampling (fig. 10); density ranged from about 62.4 pounds per cubic foot (or 1,000 kilograms per cubic meter; $\mathrm{kg} / \mathrm{m}^{3}$ ) in the middle and lower reservoir to about 74.9 pounds per cubic foot (or $1,200 \mathrm{~kg} / \mathrm{m}^{3}$ ) in the upper end, where sand content is higher. The median of all samples $\left(65.5 \mathrm{lb} / \mathrm{ft}^{3}\right.$ or $\left.1,050 \mathrm{~kg} / \mathrm{m}^{3}\right)$ was used for all subsequent calculations. Trap efficiency was assumed to be 100 percent, which is consistent with Brown (1973), who estimated trap efficiency of 95 percent using the Brune (1953) method. The reservoir is actively managed for water quality, which results in a high trap efficiency, because the city of Santa Cruz switches to a different elevation outlet if sediment is observed to be passing through the dam (Ryan Bassett, Water Resources Analyst, city of Santa Cruz, written commun., June 10, 2020). Substituting the values for $A_{L L}, D$, and $T$ in equation 1 and applying the necessary unit conversions results in the following:

$$
S L=0.0165 \cdot Y_{S}
$$

where

$$
\begin{aligned}
S L & \text { is in acre-feet per year, and } \\
Y_{s} & \text { must be specified in metric tons per year per } \\
& \text { square kilometer }\left(\mathrm{t} / \mathrm{yr} / \mathrm{km}^{2}\right) .
\end{aligned}
$$

The highest annual sediment yield for the San Lorenzo River watershed was $5,068 \mathrm{t} / \mathrm{yr} / \mathrm{km}^{2}$, in 1982 , measured at the Big Trees streamgage (USGS station 11160500), which equates to 84 acre-feet of storage loss when equation 2 is applied. For the 10-year period from 1972 to 1983, when sediment yield was measured at the Big Trees streamgage, the total storage loss computed from equation 2 was 160 acre-feet, or 16 acre-feet per year. For 2017, the year with the highest sediment yield in the recent measurements at the Santa Cruz streamgage, the sediment yield was $1,440 \mathrm{t} / \mathrm{yr} / \mathrm{km}^{2}$, which equates to 24 acre-feet of storage loss. For the period from 2009 to 2017, for which there are 6 years of available sediment yield data (2009, 2010, 2014-17; Conaway and others, 2013; East and others, 2018), application of equation 2 results in a total storage loss of 29 acre-feet, or about 5 acre-feet per year. These estimated storage losses reinforce the difficulty of detecting decadal-scale storage changes from repeat surveys: the decadal-scale changes can be similar in magnitude to survey uncertainty ( 86 acre-feet for 2009 survey and 49 acre-feet for 2019 survey). 
To make an estimate of the total storage loss since dam construction, the available sediment yield data from the San Lorenzo River watershed and equation 2 were used to hindcast reservoir storage capacity from 2019 back to 1960 as follows. First, the storage loss for all years with sediment-yield data (16 years) was computed using equation 2 . Second, relations between annual storage loss and the mean annual flow at the Big Trees streamgage (USGS station 11160500, U.S. Geological Survey, 2019) for the two periods for which there were data (1973-82, 2009-17) were developed (linear regressions to $\log$ transformed data; $\mathrm{R}^{2}=0.96$ and 0.98 , respectively, for the two periods). These two relations (fig. 15 inset) were then used to fill years without data as follows:
1960-72 filled with the 1973-82 relation; 2009-19 missing years filled with the more recent relation; 1983-2008 filled with a weighted average of the two relations that linearly transitions between the two. Computed storage-loss data are provided in table 2 . This procedure provided estimates of the storage loss for every year from 1960 to 2019 (fig. 15), which were then used to hindcast the storage capacity from the measured capacity in 2019. For the period 2009-19, the hindcasting produced an estimated total storage loss of 42 acre-feet, which is broadly consistent with the 68 acre-feet of storage loss computed for shallow areas based on the repeat surveys.

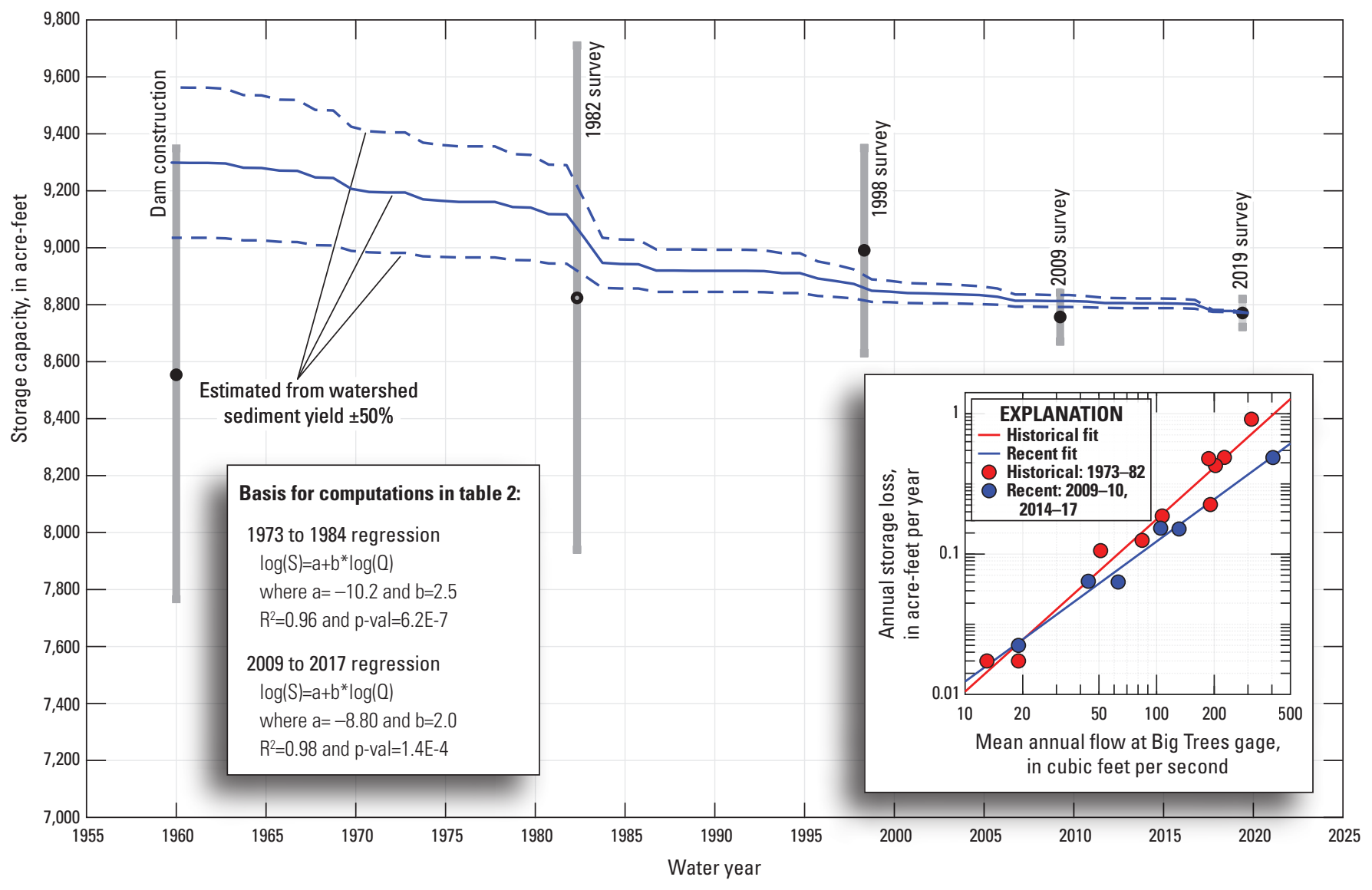

Figure 15. Storage-capacity estimates from 2019 and all previous surveys as well as hindcasted storage capacities based on watershed sediment yields and reservoir characteristics, Loch Lomond Reservoir, California. The inset shows linear regression used for the hindcasts, and the text box provides the associated equations used to compute data presented in table 2. 
22 Storage Capacity and Sedimentation Characteristics of Loch Lomond Reservoir, California, 2019

Table 2. Hindcast results using regression models shown in figure 15.

[WY, water year]

\begin{tabular}{|c|c|}
\hline WY & $\begin{array}{l}\text { Hindcast storage at the end of WY } \\
\text { (acre-feet) }\end{array}$ \\
\hline 1959 & 9,299 \\
\hline 1960 & 9,298 \\
\hline 1961 & 9,298 \\
\hline 1962 & 9,296 \\
\hline 1963 & 9,281 \\
\hline 1964 & 9,280 \\
\hline 1965 & 9,271 \\
\hline 1966 & 9,270 \\
\hline 1967 & 9,247 \\
\hline 1968 & 9,245 \\
\hline 1969 & 9,207 \\
\hline 1970 & 9,196 \\
\hline 1971 & 9,194 \\
\hline 1972 & 9,194 \\
\hline 1973 & 9,170 \\
\hline 1974 & 9,165 \\
\hline 1975 & 9,161 \\
\hline 1976 & 9,161 \\
\hline 1977 & 9,161 \\
\hline 1978 & 9,143 \\
\hline 1979 & 9,141 \\
\hline 1980 & 9,118 \\
\hline 1981 & 9,117 \\
\hline 1982 & 9,034 \\
\hline 1983 & 8,947 \\
\hline 1984 & 8,943 \\
\hline 1985 & 8,942 \\
\hline 1986 & 8,920 \\
\hline 1987 & 8,920 \\
\hline 1988 & 8,919 \\
\hline
\end{tabular}

\begin{tabular}{|c|c|}
\hline WY & $\begin{array}{l}\text { Hindcast storage at the end of WY } \\
\text { (acre-feet) }\end{array}$ \\
\hline 1989 & 8,919 \\
\hline 1990 & 8,919 \\
\hline 1991 & 8,919 \\
\hline 1992 & 8,918 \\
\hline 1993 & 8,911 \\
\hline 1994 & 8,911 \\
\hline 1995 & 8,892 \\
\hline 1996 & 8,883 \\
\hline 1997 & 8,873 \\
\hline 1998 & 8,849 \\
\hline 1999 & 8,846 \\
\hline 2000 & 8,841 \\
\hline 2001 & 8,840 \\
\hline 2002 & 8,838 \\
\hline 2003 & 8,836 \\
\hline 2004 & 8,834 \\
\hline 2005 & 8,828 \\
\hline 2006 & 8,814 \\
\hline 2007 & 8,814 \\
\hline 2008 & 8,813 \\
\hline 2009 & 8,813 \\
\hline 2010 & 8,811 \\
\hline 2011 & 8,806 \\
\hline 2012 & 8,806 \\
\hline 2013 & 8,805 \\
\hline 2014 & 8,805 \\
\hline 2015 & 8,804 \\
\hline 2016 & 8,802 \\
\hline 2017 & 8,778 \\
\hline 2018 & 8,778 \\
\hline 2019 & 8,771 \\
\hline
\end{tabular}


The results of this hindcast are shown in figure 15 along with previous estimates of storage capacity summarized by McPherson and others (2011, table 3). Although the uncertainty in the hindcasted storage capacity is unknown (but likely large), a \pm 50 -percent uncertainty envelope is included on figure 15 to illustrate how uncertainty in the 2019 storage-capacity estimate compares to the uncertainty in the previous estimates of storage capacity. The older surveys have a much larger uncertainty due to survey methods and the spatial uncertainty associated with those methods. The hindcasting produced an estimate of about 9,300 acre-feet for the original capacity of the reservoir, ranging from about 9,000 to 9,600 acre-feet for the 50-percent uncertainty envelope embedded into the load estimates (which is cumulated in the hindcast). This hindcasting corresponds to a storage loss of about 500 acre-feet (or 5 percent) from 1960 to 2019, or an average annual loss of about 8-9 acre-feet per year. The annual loss ranged from near-zero to as high as 80 acre-feet in 1982-83, with a more recent high of 24 acre-feet in water-year 2017. A water-year is defined as the period from October 1st of one year through September 30th of the following year and is named for the year in which it ends.

\section{Conclusions}

In May 2019, the U.S. Geological Survey, in cooperation with the city of Santa Cruz, surveyed Loch Lomond Reservoir to assess the storage capacity and sedimentation rates in the reservoir. Survey methods combined sonar soundings to measure bathymetry, lidar scans to measure near-shore topography, and bed-sediment samples to understand reservoir bed-material size. The survey produced a bare-earth digital elevation model of the reservoir at a resolution of 1 square meter or better to elevations at or above the reservoir spillway elevation and provided the coverage needed to estimate storage capacity. Additionally, we compared the 2019 survey to historical surveys and provided a hindcast estimate of sediment yield to the reservoir to evaluate long-term changes in storage-capacity. The results are listed as a summary.

(1) Storage capacity from the 2019 survey was $8,770 \pm 50$ acre-feet, which was nearly the same as the storage capacity from the 2009 survey if the correct spillway elevation was used $(8,760 \pm 90$ acre-feet). Thus, the total storage-capacity change between the two surveys was indeterminate when survey uncertainty was considered.

(2) The differences in storage between 2009 and 2019 varied substantially with depth. In shallow areas where depths were less than $30 \mathrm{ft}$ (at full pool), such as the very upstream end of the reservoir, storage loss (sediment deposition) dominated and was about 68 acre-feet from 2009 to 2019. This was consistent with previous studies of the reservoir as well as field observations during the 2019 survey; in addition, the elevation changes were large enough to preclude survey error as an explanation. In areas deeper than $30 \mathrm{ft}$, persistent small storage gains over a wide range of depths totaled 82 acre-feet from 2009 to 2019. Because the magnitude of the changes was similar to survey uncertainty, survey error cannot be ruled out as an explanation for the computed storage gains. Another possible explanation for storage increases in deep areas was the consolidation of sediment over time as the bulk density of deposited sediment increases (porosity decreases), potentially causing the gradual lowering of bed elevations and increasing storage over time.

(3) Further exploration of consolidation processes in the reservoir, such as using coring and the evaluation of bulk density as a function of depth in the cores, could help explain storage gains in the deeper parts of the reservoir.

(4) Independent storage-loss estimates from watershed sediment yields and reservoir characteristics were similar in magnitude to storage losses computed from repeat surveys. Sediment yields were used to hindcast estimates of annual reservoir storage capacity from 2019 back to 1960 , when the dam was constructed. This hindcasting produced an estimate of about 500 acre-feet of total storage loss for the history of the reservoir, or about 8-9 acre-feet/year on average for the 60-year period. Although the uncertainty of this estimate is unknown, this estimate provides valuable information about long-term changes that offers context to changes based on repeat surveys. 


\section{References Cited}

Best, T.C., and Griggs, G.B., 1991, A sediment budget for the Santa Cruz littoral cell, California, in Osborne, R.H., ed., From shoreline to abyss - Contributions in marine geology in honor of Francis Parker Shepard: SEPM Society of Sedimentary Geology, v. 46, p. 35-50, https://doi.org/10.2110/pec.91.09.0035.

Brown, W.M., III, 1973, Erosion processes, fluvial sediment transport, and reservoir sedimentation in a part of the Newell and Zayante Creek Basins, Santa Cruz County, California: U.S. Geological Survey Open-File Report 73-35, 31 p., https://doi.org/10.3133/ofr7335.

Brune, G.M., 1953, Trap efficiency of reservoirs: Eos, Transactions American Geophysical Union, v. 34, no. 3, p. 407-418, https://doi.org/10.1029/TR034i003p00407.

Conaway, C.H., Draut, A.E., Echols, K.R., Storlazzi, C.D., and Ritchie, A., 2013, Episodic suspended sediment transport and elevated polycyclic aromatic hydrocarbon concentrations in a small, mountainous river in coastal California: River Research and Applications, v. 29, no. 7, p. 919-932, https://doi.org/10.1002/rra.2582.

East, A.E., Stevens, A.W., Ritchie, A.C., Barnard, P.L., Campbell-Swarzenski, P., Collins, B.D., and Conaway, C.H., 2018, A regime shift in sediment export from a coastal watershed during a record wet winter, California - Implications for landscape response to hydroclimatic extremes: Earth Surface Processes and Landforms, v. 43, no. 12, p. 2562-2577, https://doi.org/10.1002/esp.4415.

Edwards, T.K., and Glysson, G.D., 1999, Field methods for measurement of fluvial sediment: U.S. Geological Survey Techniques of Water-Resources Investigations, book 3 , chap. C2, 89 p., https://pubs.usgs.gov/twri/twri3-c2/.

Environmental Systems Research Institute, Inc. (ESRI), 2017, ArcGIS version 10.5: Redlands, Calif., Environmental Systems Research Institute, Inc., https://www.esri.com/enus/arcgis/products/arcgis-online/overview.

Fogelman, R.P., and Johnson, K.L., 1985, Capacity and sedimentation of Loch Lomond Reservoir, Santa Cruz County, California: U.S. Geological Survey Open-File Report 85-485, 24 p., https://doi.org/10.3133/ofr85485.

Guy, H.P., 1969, Laboratory theory and methods for sediment analysis - Laboratory analysis: U.S. Geological Survey Techniques of Water-Resources Investigations, book 5, chap. C1, 59 p., https://doi.org/10.3133/twri05C1.
Lara, J.M., and Pemberton, E.L., 1963, Initial unit weight of deposited sediments, Paper 82, U.S. Department of Agriculture: Miscellaneous Publication, v. 970, p. 818-845.

Marineau, M.D., and Wright, S.A., 2017, Bed-material characteristics of the Sacramento-San Joaquin Delta, California, 2010-13: U.S. Geological Survey Data Series 1026, 55 p., https://doi.org/10.3133/ds1026.

Marineau, M.D., Wright, S.A., and Lopez, J.V., 2020, Storage capacity and sedimentation characteristics of the San Antonio Reservoir, California, 2018: U.S. Geological Survey Scientific Investigations Report 2019-5151, 34 p., https://doi.org/10.3133/sir20195151.

MathWorks, Inc., 2018, Matlab version R2018a software: Natick, Mass., MathWorks Inc., https://www.mathworks.com/help/matlab/release-notesR2018a.html.

McPherson, K.R., and Harmon, J.G., 2000, Storage capacity and sedimentation of Loch Lomond Reservoir, Santa Cruz, California, 1998: U.S. Geological Survey Water-Resources Investigations Report 00-4016, 16 p., https://ca.water.usgs.gov/archive/reports/wrir004016/.

McPherson, K.R., Freeman, L.A., and Flint, L.E., 2011, Analysis of methods to determine storage capacity of, and sedimentation in, Loch Lomond Reservoir, Santa Cruz County, California, 2009: U.S. Geological Survey Scientific Investigations Report 2011-5141, 88 p., https://doi.org/10.3133/sir20115141.

Morris, G.L., and Fan, J., 1998, Reservoir sedimentation handbook: New York, McGraw-Hill, 805 p.

Morris, G.L., Annandale, G., and Hotchkiss, R., 2008, Reservoir sedimentation, chap. 12 of Garcia, M.H., ed., Sedimentation engineering-Processes, measurements, modeling, and practice: ASCE Manuals and Reports on Engineering Practice No. 110, p. 579-612, https://doi.org/10.1061/9780784408148.

Schleiss, A.J., Franca, M.J., Juez, C., and De Cesare, G., 2016, Reservoir sedimentation: Journal of Hydraulic Research, v. 54, no. 6, p. 595-614, https://doi.org/10.1080/00221686.2016.1225320.

U.S. Geological Survey, 2019, USGS water data for the Nation: U.S. Geological Survey National Water Information System database, accessed October 1, 2019, at https://doi.org/10.5066/F7P55KJN.

Whealdon-Haught, D.R., Wright, S.A., and Marineau, M., 2021, Loch Lomond Reservoir 2019 survey data: U.S. Geological Survey data release, https://doi.org/10.5066/P91BUQWP. 


\title{
Appendix 1. Bowman and Williams 2012 Memo to the City of Santa Cruz
}

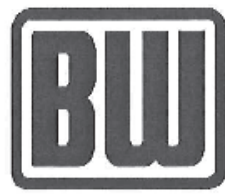

\author{
BOWMAN \&6 WILLIAMS \\ CONSULTING CIVIL ENGINEERS \\ A CALIFORNIA CORPORATION \\ 1011 CEDAR - PO BOX 1621 • SANTA CRUZ, CA 95061-1621 \\ PHONE (831) 426-3560 FAX (831) 426-9182 \\ EMAIL: bryan@bowmanandwilliams.com
}

October 9, 2012

Santa Cruz City Water Department

ATTN: Ryan Ernst, Assistant Engineer

809 Center Street, Room 102

Santa Cruz, Ca. 95060

Re: Newell Creek Dam elevation benchmark verification, and new benchmarks for the Newell Dam Monitoring Project.

Dear Ryan,

Bowman and Williams has completed the differential leveling for the Newell Creek Dam. We utilized NGS (National Geodetic Survey) benchmark Y 1460 for the project. The benchmark information is as follows:

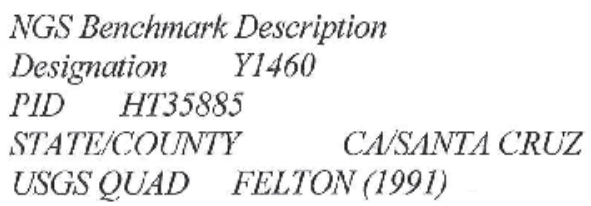

Marker Vertical Control Disk

Setting Set in abutment or pier of a large bridge

Stamping $\quad$ Y 14601990

Elevation NAVD $88=313.00 \mathrm{ft}$.

Elevation NGVD $29=310.27$ ft. (Superseded)

Benchmark Location

In Glen Arbor at the Intersection of Glen Arbor Road and a Bridge spaming Newell Creek, set in lop of and near the soultwest end of the southeast abutment of the bridge (Number 29 3307-BR 0.9, 3.2 M (10.5 fi.) southwest of and level with the road centerline, $0.1 \mathrm{~m}(0.3 \mathrm{ft}$.) northeast of the southwest bridge guard rail, and $0.1 \mathrm{M}(0.3 \mathrm{ft}$.) northwest of the southeast end f the guard rail.

We have also attached the NGS (National Geodetic Survey) data sheet to this report for your reference. This letter will serve as a report on the elevations of the dam monitoring points based on both the current elevations used for monitoring, and also the elevations based on the NGS (National Geodetic Survey) benchmark.

Our field crews performed the leveling fieldwork on September 20, 2012, and finished on October 1, \& October 2, 2012. We used the published NAVD88 elevation of the NGS (National Geodetic Survey) benchmark to verify the existing monitoring control points at the dam. We determined the elevations of the same point that we use to make our annual dam measurement report. 'The annual monitoring report identifies the point as "Point $\mathrm{Y}$ ". The point is a "PK" Nail located in the southcast wing wall of the spillway with an elevation $=590.15$ " feet based on the current monitoring control elevations. A sccond Bcnchmark exists at the northwest end of the dam and is referred to as Pont " $\mathrm{X}$ ". This is a nail and tin in the top of a 2 " diameter iron pipe having an elevation of $591.225 \mathrm{ft}$. 
The current monitoring elevations shown are based on historical information from the dam monitoring that has been performed by our offices since the dam monitoring began. The current NGS benchmark is based on a NAVD88 elevation datum, but has values for the superseded NGVD29 datum elevation of the point. In this report, we will show the values for the elevations of the current historical monitoring control, and also the elevations as determined from the NGS (National Geodetic Survey) benchmark in both the NAVD88 \& NGVD29 datum.

We determined the elevations of the points (or benchmarks) as follows:

\begin{tabular}{l|ccc}
\hline IDENTIFIER & $\begin{array}{l}\text { CURRENT DAM } \\
\text { MONITORING } \\
\text { ELEVATION }\end{array}$ & $\begin{array}{c}\text { NGVD29 ELEVATION } \\
\text { (NAVD88-2.730') } \mathrm{ft} .\end{array}$ & $\begin{array}{c}\text { NAVD88 ELEVATION } \\
\mathrm{ft} .\end{array}$ \\
\hline POINT B & 589.239 & 590.200 & 592.930 \\
POINT X & 591.225 & 592.188 & 594.918 \\
POINT Y & 590.150 & 591.112 & 593.842 \\
NW WEIR SPILLWAY & 577.185 & 578.147 & 580.877 \\
SE WEIR SPILLWAY & 577.174 & 578.136 & 580.866 \\
\hline
\end{tabular}

All elevations shown are in feet and decimals thereof.

In addition to the above points, we also set established 2 benchmarks near the dam site. The horizontal location of those points will be provided in a separate report during our next dam monitoring survey. The Elevations of the Benchmarks are as follows:

\begin{tabular}{l|ccc}
\hline IDENTIFIER & $\begin{array}{c}\text { CURRENT DAM } \\
\text { MONITORING } \\
\text { ELEVATION }\end{array}$ & $\begin{array}{c}\text { NGVD29 ELEVATION } \\
\text { (NAVD88-2.73') ft. }\end{array}$ & $\begin{array}{c}\text { NAVD88 ELEVATION } \\
\mathrm{ft.}\end{array}$ \\
\hline Rail Road Spike & 356.920 & 357.882 & 360.612 \\
Rail Road Spike \#2 & 368.881 & 369.843 & 372.573 \\
\hline
\end{tabular}

All elevations shown are in feet and decimals thereof.

If you have any questions, please do not hesitate to call.

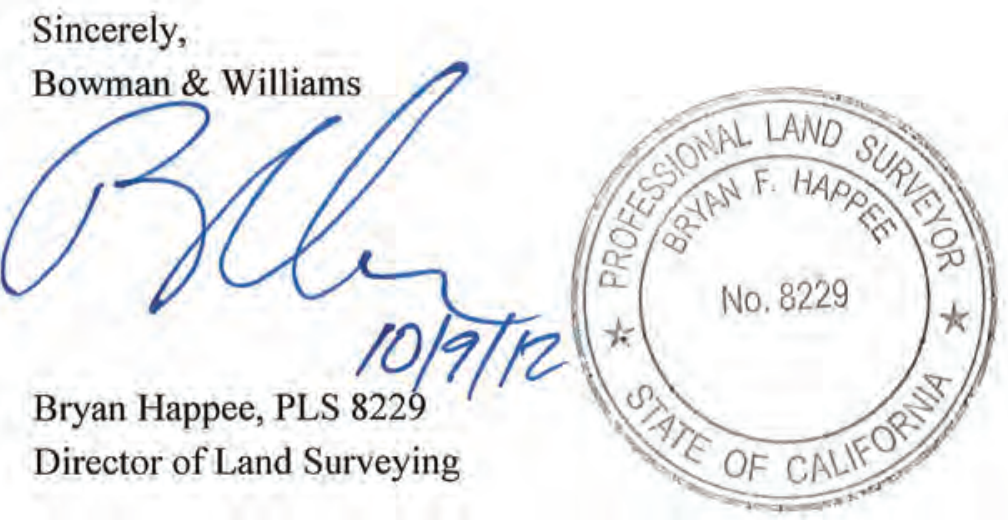




\title{
Appendix 2. Bowman and Williams 2017 Memo to the City of Santa Cruz
}

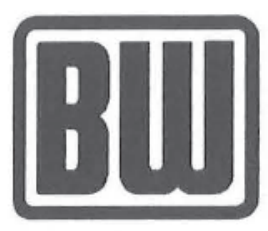

\author{
BOWMAN 8๘ WILLIAMS \\ CONSULTING CIVIL ENGINEERS \\ A CALIFORNIA CORPORATION \\ 1011 CEDAR • PO BOX 1621 • SANTA CRUZ, CA 95061-1621 \\ PHONE (831) 426-3560 FAX (831) 426-9182 \\ EMAIL: bryan@bowmanandwilliams.com
}

October 26,2017

City of Santa Cruz Water Department

Leah VanDerMaaten.

212 Locust Street, Suite C

Santa Cruz, CA 95060

LVanDerMaaten@cityofsantacruz.com

Re: Benchmark 2012 Level Loop \& ongoing work at the Newell Creek Dam.

Dear Leah Van Der Maaten,

Per your request, we are providing this letter to address three issues: (1) Verify the elevations of "Point Y" are accurate in the Bowman \& Williams (B\&W) letter to the City of Santa Cruz dated October 9, 2012; (2) Verify the historic benchmark, Point Y, at the Newell Creek Dam is not linked to NGVD29 or the NAVD88 Elevation Datum.; (3) Recommend Elevations of the Newell Creek Dam Site and the benchmarks that should be used on site during any of the ongoing studies or the ongoing annual monitoring of the dam.

\section{Verify the elevations of Point $Y$ are accurate in the October 9,2012 B\&W letter to the City}

The City asked B\&W to verify the accuracy of the elevations provided by B\&W in the letter to the City of Santa Cruz, dated October 9, 2012. In August 2017, B\&W checked the Benchmark 2012 Level Loop by resurveying the area between NGS benchmark number Y1460 and Point Y at the dam. The elevations provided in the $2012 \mathrm{~B} \& \mathrm{~W}$ letter were confirmed to be accurate.

2. Verify the historic benchmark elevation, Point $Y$, at the Newell Creek Dam is not linked to NGVD29 or the NAVD88 Elevation Datum

It is assumed, that at the time the dam was constructed, surveyors would have used the NGVD29 datum. However, as we explained in a letter to the City of Santa Cruz dated October 9, 2012, the elevation of Point Y using the NGVD29 datum does not match the elevation of Point Y using the "Current/Historical Dam Monitoring Elevation". The current and historic elevation of point $\mathrm{Y}$ is 590.15 feet; while the elevation of point $\mathrm{Y}$ using NGVD 29 datum is 591.112 feet. The two different elevations of Point $\mathrm{Y}$ appear to be off by approximately 1 foot which may have been caused by an error during one of the original surveys in 1961 but this has not been verified.

It is important to note that the 2012 Letter provides necessary values for the City to convert current dam monitoring elevations and surveys into either the NGVD29 or NAVD88 datum. When reading the 2012 Letter, it is important for the City to understand that Point $\mathrm{Y}$ is a site-specific benchmark for most current and historic dam surveys conducted by the City and B\&W. Individual drawings will reference the benchmark \& datum used. The Point Y position and elevation is currently monitored for changes in elevation during our survey in both the horizontal and vertical for any large change in position or elevation, but the point has not been subject to any large changes since the dam was constructed and monitoring began. The minor differences in the point are assumed to not change the elevation of Point Y. 


\section{Recommended elevation of benchmark for ongoing studies or monitoring of the Newell Creek Dam}

As you know, the Newell Creek Dam monitoring and other site improvements have been ongoing with B\&W and the City of Santa Cruz since the completion of the dam. The baseline for the monitoring survey was performed on February 17, 1961. At that time, the Elevation of Point $Y$ was shown to be at an elevation of 590.15 feet, but there is no information available on how the elevation of Point $Y$ was established. Attached to this letter is a document prepared by the City of Santa Cruz Department of Engineering entitled "Newell Creek Dam" showing the elevation of Point $Y$ from the base survey to be $590.15 \mathrm{ft}$. A copy of the Index sheet is also attached for reference.

The construction drawings prepared by Creegan \& D'Angelo entitled "City of Santa Cruz, Santa Cruz County, California Newell Dam Project", that were prepared for the construction of the dam state on the Index Sheet that "Elevations are based on Santa Cruz County Benchmark on the Southwest abutment of Newell Creek Bridge at Glen Arbor Rd", but no elevation or description of the benchmark is provided.

It is our opinion is that the historic elevation of 590.15 feet for POINT Y is preferred for all future improvement projects, and also as the base elevation for the annual Monitoring of the dam, or any studies performed by outside agencies since the Baseline survey, Point $Y$ has been held as a constant, and is the current elevation that is held for all of the work that Bowman \& Williams does at the dam site, and also for the ongoing annual monitoring of the dam. During any construction project or any study that is done, the City should require that POINT Y and the historic elevation of 590.15 feet SHALL be used as the elevation benchmark, and referenced on any map or in any report prepared. The location of POINT Y is out of the way enough that it should continue to be accessible and is also protected from being destroyed during any construction projects that may take place in the future. In addition, our annual monitoring memorializes the elevations of all monitoring points in relation to the elevation of POINT Y, so there is a check that is done on an annual basis that indicates any movement to the points, and there is also a measurement taken in relation to the baseline of the dam that checks for any movement of POINT Y.

When POINT Y is referenced on any drawing, or referred to in any report, it should contain the following note:

The Benchmark for (Map or Study) is based on Point $Y$ of the Newell Creek Dam and is located on the eastern wing wall of the spillway on the axis of the dam, Elevation $=\mathbf{5 9 0 . 1 5}$ feet and is based on the Newell Creek Dam Elevation Datum,. No reference to the NGVD29 or the NAVD88 Elevation Datum should be contained in the note or on the plan.

In the future, if any projects or studies are being performed, and it is more desirable to have a benchmark near the project site, a licensed surveyor would be able to transfer an elevation form POINT Y to a point near the work being performed.

We hope that this letter proves useful for the ongoing work and monitoring at the dam site. If you have any question or comments, please feel free to contact me.

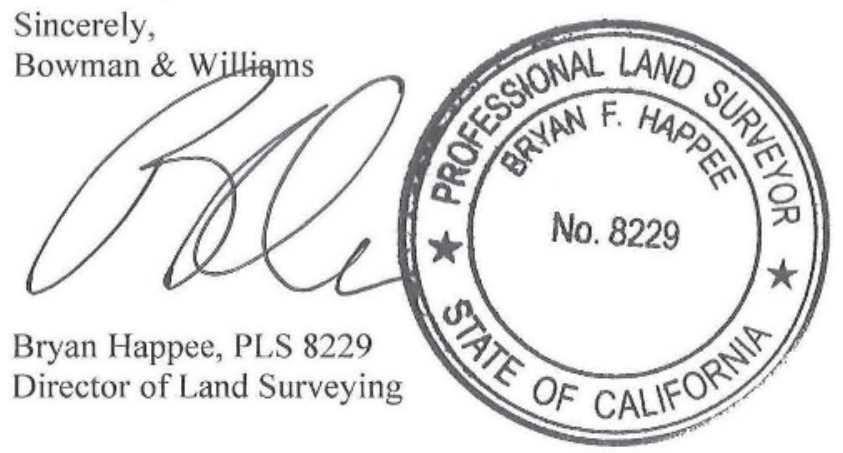


For more information concerning the research in this report, contact the

Director, California Water Science Center

U.S. Geological Survey

6000 J Street, Placer Hall

Sacramento, California 95819

https://ca.water.usgs.gov

Publishing support provided by the U.S. Geological Survey Science Publishing Network, Sacramento Publishing Service Center 
